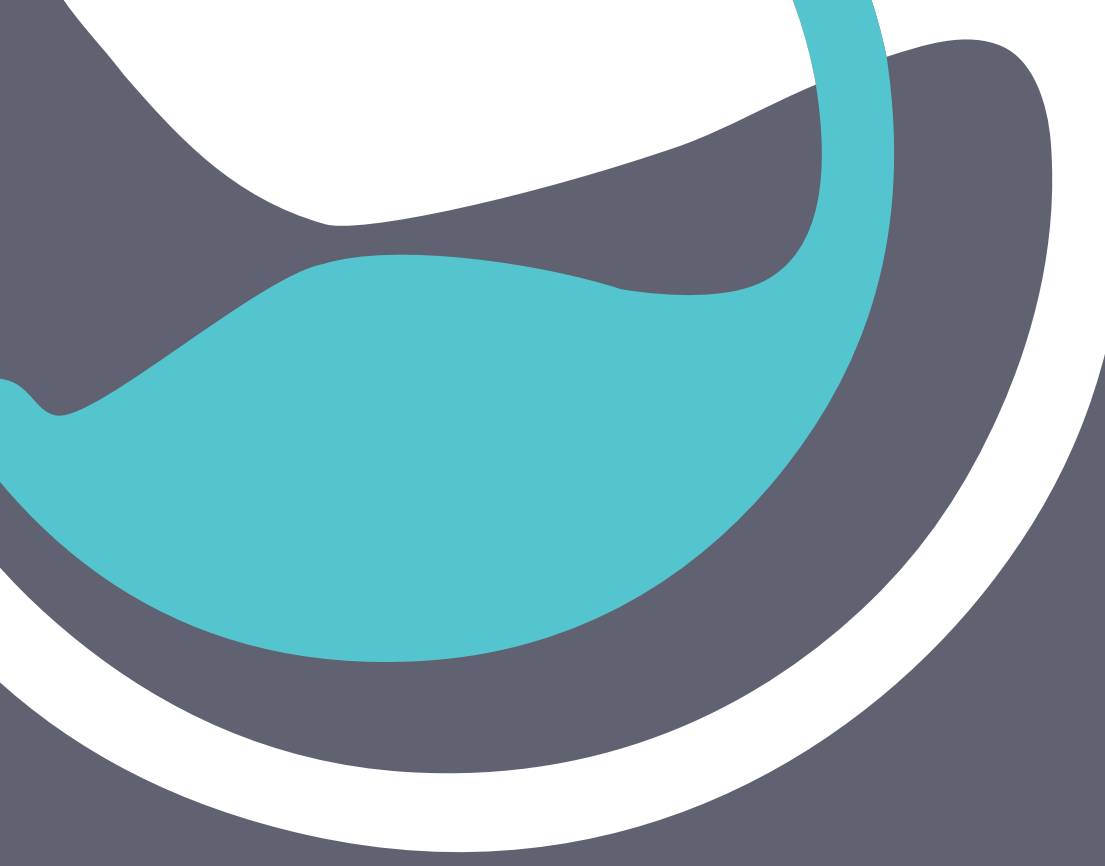

$$
\mathrm{ICTD}
$$

Working Paper 22

\title{
Tax Structures, Economic Growth and Development
}

Kyle McNabb and Philippe LeMay-Boucher

September 2014 
ICTD Working Paper 22

\section{Tax Structures, Economic Growth and Development}

Kyle McNabb and Philippe LeMay-Boucher

September 2014 
Tax Structures, Economic Growth and Development

Kyle McNabb and Philippe LeMay-Boucher

ICTD Working Paper 22

First published by the Institute of Development Studies in September 2014

(C) Institute of Development Studies 2014

ISBN: 978-1-78118-175-1

A catalogue record for this publication is available from the British Library.

All rights reserved. Reproduction, copy, transmission, or translation of any part of this publication may

be made only under the following conditions:

- with the prior permission of the publisher; or

- with a licence from the Copyright Licensing Agency Ltd., 90 Tottenham Court Road, London W1P 9HE, UK,

or from another national licensing agency; or

- under the terms set out below.

This publication is copyright, but may be reproduced by any method without fee for teaching or nonprofit purposes, but not for resale. Formal permission is required for all such uses, but normally will be granted immediately. For copying in any other circumstances, or for reuse in other publications, or for translation or adaptation, prior written permission must be obtained from the publisher and a fee may be payable.

Available from:

The International Centre for Tax and Development

at the Institute of Development Studies,

Brighton BN1 9RE, UK

Tel: +44 (0) 1273606261 Fax: +44 (0) 1273621202

E-mail: info@ictd.ac.uk

Web: www.ictd/en/publications 


\title{
Tax Structures, Economic Growth and Development
}

\author{
Kyle McNabb and Philippe LeMay-Boucher
}

\section{Summary}

This paper investigates the relationship between tax structures and economic growth in a panel of developed and developing countries. In order to raise revenue, low-income countries have historically relied more heavily on international trade taxes, whilst richer nations employ comparatively more consumption and income taxes. Using the new Government Revenue Dataset (GRD) from the International Centre for Tax and Development (ICTD), we consider the effects of revenue-neutral changes in tax structure on economic growth for a panel of over 100 countries with data covering the period 1980-2010. Results from the Common Correlated Effects Mean Group (CMG) estimator (Pesaran 2006) find that increases in income taxes (specifically personal income taxes) offset by reductions in trade or consumption taxes have had a negative impact on GDP growth rates. We also highlight the fact that trade liberalisation has not had any discernible positive effects on economic growth. Revenue-neutral increases in personal income taxes are found to be particularly harmful in middle- and low-income countries. Taken alongside the results of, for example, Baunsgaard and Keen (2010), this is a reminder of the difficulties of tax reform for developing countries.

Keywords: tax structure; fiscal policy; economic growth; development.

Kyle McNabb is a PhD candidate at Heriot-Watt University. His research interests include the economics of informal financial institutions, fiscal policy in developing countries, foreign aid, and panel time series econometrics.

Philippe LeMay-Boucher is a lecturer in Development Economics at Heriot-Watt University. His research encompasses a broad range of topics which investigate intra-household financial decisions: membership of informal saving and insurance groups, subscription to formal health micro-insurance, and intra-household consumption allocation decisions. 


\section{Contents}

Summary 3

Acknowledgements $\quad 5$

Acronyms $\quad 5$

Introduction $\quad 6$

$\begin{array}{lll}1 & \text { Theoretical predictions } & 7\end{array}$

$\begin{array}{llr}2 & \text { Empirical findings } & 8\end{array}$

$3 \quad$ Fiscal policy and development 11

$4 \quad$ Trends in the data $\quad 12$

$\begin{array}{lll}5 & \text { Econometric approach } & 18\end{array}$

6 Results 20

6.1 Full sample 20

$\begin{array}{lll}6.2 & \text { Results by country grouping } & 27\end{array}$

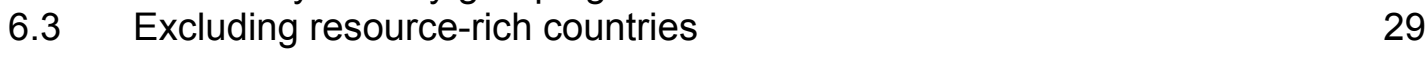

$7 \quad$ Limitations and possibilities for further research 32

8 Conclusions 33

Appendix 1 Summary statistics 34

Appendix 2 Country list (full sample) 35

$\begin{array}{ll}\text { References } & 36\end{array}$

Tables

Table 1

Table 2a

Table $2 b$

Table 3a

Table 3b

Table $4 a$

Table $4 \mathrm{~b}$

Table 5

Table 6

Table 7

Table 8

Tax revenue as \% of GDP 11

Full sample, pooled specifications, indirect taxes omitted 21

Full sample, heterogeneous specifications, indirect taxes omitted 22

Full sample, pooled specifications, trade taxes omitted 23

Full sample, heterogeneous specifications, trade taxes omitted 24

Full sample, pooled specifications, consumption taxes omitted 25

Full sample, heterogeneous specifications, consumption taxes omitted 26

CMG regressions, separate PIT and CIT categories 27

MG regressions by income group $\quad 28$

CMG regressions excluding resource-rich countries 30

MG regressions by income group, excluding resource-rich countries 31

Figures

Figure 1

Figure $2 a$

Direct-indirect split by decade and income group

13

Tax structure 1980-2009: low-income countries 14

Figure $2 b$

Tax structure 1980-2009: middle-income countries

14

Figure 2c

Tax structure 1980-2009: high-income countries

15

Figure 2d

Tax structure 1980-2009: OECD countries

Figure 3a Tax structure, including subdivisions of income tax 1990-2009: lowand middle-income countries

Figure 3b Tax structure, including subdivisions of income tax 1990-2009: highincome countries 


\section{Acknowledgements}

We are grateful for useful comments from Chris Adam, Wilson Prichard, Alex Cobham and two anonymous referees, amongst others. All remaining errors are our own.

\section{Acronyms}

$\begin{array}{ll}\text { CCEP } & \text { Common Correlated Effects Pooled } \\ \text { CIT } & \text { Corporate Income Taxes } \\ \text { CMG } & \text { Common Correlated Effects Mean Group } \\ \text { CSD } & \text { Cross-sectional Dependencies } \\ \text { EU } & \text { European Union } \\ \text { FE } & \text { Fixed Effects } \\ \text { GDP } & \text { Gross Domestic Product } \\ \text { GRD } & \text { Government Revenue Dataset } \\ \text { ICTD } & \text { International Centre for Tax and Development } \\ \text { IMF } & \text { International Monetary Fund } \\ \text { IV } & \text { Instrumental Variable } \\ \text { MDG } & \text { Millennium Development Goal } \\ \text { MG } & \text { Mean Group } \\ \text { NAFTA } & \text { North American Free Trade Agreement } \\ \text { OECD } & \text { Organisation for Economic Cooperation and Development } \\ \text { PIT } & \text { Personal Income Taxes } \\ \text { PMG } & \text { Pooled Mean Group } \\ \text { POLS } & \text { Pooled Ordinary Least Squares } \\ \text { RMSE } & \text { Root Mean Squared Error }\end{array}$




\section{Introduction}

The past thirty years have seen sweeping changes in the means by which many countries collect fiscal revenues. From a heavy reliance on trade taxes in the early 1980s, many lowincome countries, with guidance and support from the International Monetary Fund (IMF), have changed focus to increase the use of consumption taxes such as Value Added Tax (VAT). The impact of such structural shifts on economic growth is intriguing. Whilst the vast majority of studies in this area have focused only on Organisation for Economic Cooperation and Development (OECD) countries, the new Government Revenue Dataset (GRD) from the ICTD, rich with information on revenue streams in developing countries, allows us to assess the impact of revenue-neutral shifts in tax structure on historic per capita GDP growth rates in a panel of over 100 countries.

Authorities in developing countries are faced with a very challenging set of circumstances when it comes to tax collection. Issues such as weak administration, low literacy levels, low population density and a large shadow economy necessitate that not only is overall revenue low but the tax structure is less reliant on income taxes, with a heavier weight placed upon trade taxes that are more easily collected. Trends in the data show that low- and middleincome countries have seen large changes in their tax structures since 1980, yet richer nations have had a relatively stable tax composition. The on-going trends of globalisation and IMF support for a move towards consumption taxes have been instrumental in seeing low- and middle-income countries' reliance on trade taxes decrease. Yet questions remain over the impact of such structural shifts in taxation: Baunsgaard and Keen (2010) highlight that revenue recovery following the changes in low-income countries has been poor; less still is known about the impacts on GDP growth.

The endogenous growth models of, inter alios, Mendoza et al. (1997) provide a theoretical background for this study. They predict that taxes on corporate or personal income distort decisions leading to productive investments in human or physical capital to a greater extent than consumption taxes. Therefore, it is interesting to see if such effects show up in an empirical context. However the disparity between theory and empirics is one issue that must be overcome: the relevant theoretical models rely on marginal tax rates, yet these are not readily available (or easily identifiable) for a large panel of countries. Similarly, including the tax ratio (i.e. total revenue as a percentage of GDP) is a rather crude proxy for the tax rate. We thus examine the effects of revenue-neutral changes in the tax structure (i.e. holding total receipts constant); results from the Common Correlated Effects Mean Group (CMG) estimator (Pesaran 2006), which allows for full country heterogeneity and accounts for crosssectional dependencies, suggest that shifts away from trade and consumption towards income taxes have had negative impacts on GDP growth rates. Specifically, we find that this effect is felt most strongly through personal income taxes (PIT). Therefore we are able to present new evidence, highlighting the potentially harmful effects of trade liberalisation on GDP growth rates.

The following Sections ( 1 and 2) provide an overview of the relevant theoretical predictions and empirical evidence that exists with regard to fiscal policy and growth. Section 3 considers the specific issues relevant to developing countries with regard to revenue mobilisation. In Section 4 we present some descriptive statistics and a graphical analysis of the recent trends in tax structures. The following Section (5) discusses the econometric issues with large $N$, large $T$ panels, and provides justification for our choice of empirical strategy. The results, and a discussion, are presented in Section 6 . Section 7 examines some of the inherent limitations of the present work, before Section 8 concludes. 


\section{Theoretical predictions}

This section provides a brief overview of the theoretical predictions surrounding the relationship between taxation and output growth. ${ }^{1}$ In terms of the level of taxation, that is to say tax revenue expressed as a percentage of GDP, it is not immediately clear whether a higher level of taxes would have a positive or negative effect on output. Whilst higher tax rates distort the incentive for individuals and firms to engage in activities that contribute towards higher levels of output, higher revenue can provide the government with a greater ability to design policies that can increase the productive capacity of the economy (such as investment in education and training, or subsidies for research and development). Thus, the relationship between the levels of taxation and output is more likely to be determined by 'societal choices as to the appropriate level of public spending' (Arnold et al. 2011: F59).

The neoclassical growth model (inter alios Swan 1956; Solow 1956) does not provide scope for assessing the potential for fiscal policy to affect the long-run steady-state growth rate; in this model a change in the tax rate may lead to a shift in the steady-state growth path, but not in its slope. This is illustrated in King and Rebelo (1990), who calibrate the neoclassical model with parameters consistent with the long-run US experience to show that an increase in an output tax from 20 to 30 per cent leads to a new, lower steady-state growth path. ${ }^{2}$ In order to find theoretical predictions of the effects of fiscal policy on output growth, however, one must look to works such as Barro (1990), King and Rebelo (1990) or Mendoza et al. (1997). Specifically, these models consider changes in the tax rate. King and Rebelo's model (1990: 130) considers the effects of a rise in the 'output tax rate applied equally to all sectoral activities'. The authors conclude that whilst 'taxation may affect the growth rate in a quantitatively important way ... the magnitude of this influence depends ... on the production and tax structure' (King and Rebelo 1990: 140). The endogenous growth model outlined in Mendoza et al. (1997) however goes further, in that it considers the effects of marginal tax rates on physical capital, human capital and consumption. The model predicts that whilst all three affect the 'net after-tax rate of return on physical capital', consumption taxes will do so only indirectly through the labour-leisure choice, which in turn affects the ratio of capital to labour used in production. Higher consumption taxes increase the cost of consumer goods, in turn reducing the reward for working, thus impacting the labour supply (Arnold et al. 2011). Taxes on physical or human capital, however, influence growth through both direct effects on labour supply and indirect effects on the labour-leisure choice. ${ }^{3}$ Whilst the magnitude of these impacts is dependent on factors such as the elasticity of labour supply, the predictions of the model are clear: there are fewer channels through which consumption taxes can distort growth (as measured by the return on physical capital) than with the other two tax categories.

Arnold et al. (2011) also regard consumption taxes to be the least harmful to growth in the sense that they do not discourage savings or investment. The authors consider that personal income taxes (PIT) are more detrimental to growth than consumption taxes, but not to the extent of corporate income taxes (CIT), which are viewed as the most harmful. It is also suggested that higher rates of PIT reduce the incentive to save, which, at least to some extent, reduces the finance available to small businesses, limiting their growth potential. ${ }^{4}$ Corporate income taxes are considered to be the least growth-friendly, in the sense that they

A comprehensive review can be found in Myles (2007).

See King and Rebelo (1990: 131 Figure 1).

See Mendoza et al (1997:102-106) for detailed derivations and results.

This point might also be made for consumption taxes. Higher VAT rates (for example) might discourage consumers from purchasing expensive items. If consumers choose to save those funds that would otherwise have been spent, then this might improve the liquidity available to small and medium-sized enterprises. Thus the negative effect on growth of reduced consumption expenditure might, at least to some extent, be offset by better lending conditions for small businesses. 
discourage investments most important for growth - such as in capital or improvements in productivity. Furthermore, Arnold et al. (2011) consider that CIT provisions may exist to divert resources from the industries where they make the most significant contribution to growth.

One feature of the models mentioned above (and, indeed, with much of the empirical literature) is that they make little explicit attempt to incorporate the role of trade taxes. Given the wide developing country coverage at our disposal, this is an issue on which we need to focus. There are, however, a few easily identifiable channels through which trade taxes affect the investment decisions that lead to growth. Indeed, as it turns out, the distortions created by trade taxes can be viewed as analogous to those created by corporation or consumption taxes. Consider, firstly, a high prevalence of protectionist tariffs, which might imply that resources are flowing to inefficient industries where it might not otherwise be profitable to operate. To the extent that this distorts the flow of human or physical capital, import tariffs can be viewed as distorting the investment necessary for growth. Thus these taxes can be considered to have similar effects as PIT or CIT. Todaro and Smith (2009) consider that an import duty might actually serve as a proxy for taxes on corporate profits, in the sense that companies relying on imports for inputs in the production process are not always able to pass on the full burden of the tariff to consumers. To the extent that import duties are passed on to consumers through higher prices, the effect of such a tax is analogous to that of domestic consumption taxes such as VAT. The aforementioned authors consider export duties as an effective means of taxing the profits of firms who sell their produce abroad, whilst also noting that there is a clear trade-off between raising revenue and discouraging firms from exporting their produce; the efficiency gains from exposure to international trade have obvious implications for growth.

It is thus clear that trade taxes can foster significant distortions in terms of the flow of human and physical capital. The extent (and direction) of the effect on growth of trade taxes is however dependent on the trade patterns of the country in question. Economies that rely more heavily on imports or exports will have a greater potential to influence economic growth through protectionist trade policies than will a more closed economy. This distinction is particularly relevant for developing economies, many of which are heavily reliant on trade and, as such, on revenue from trade taxes. The features of fiscal policy specific to developing countries are discussed in detail in Section 3 below.

The aforementioned endogenous growth models provide a sound theoretical basis for examining the effects of various tax categories on economic growth (or, at the very least, the investment decisions that influence growth). The work of Mendoza et al. (1997) is particularly illustrative of the various distortions to growth arising from the choice of tax rate. A major issue however lies in the fact that their model deals with marginal tax rates. There thus exists somewhat of a disparity between the theoretical and empirical literature, as data on tax rates is not readily available for a large number of countries over a long time period. The next section details the attempts that have been made to overcome this issue.

\section{Empirical findings}

Following Easterly and Rebelo's claim (1993: 442) that 'The evidence that tax rates matter for growth is disturbingly fragile', the empirical growth literature has made great strides towards more accurately isolating the effects of changes in taxation. Improvements in both the quality and quantity of data have improved the options available to researchers. It certainly appears at this point that, contrary to Easterly and Rebelo's claim, taxes do matter for growth; which taxes, where and by how much they affect growth are perhaps the more stimulating questions. This section contains an overview of the empirical evidence, and provides an assessment of the results reported to date. 
Early studies examining the relationship between tax and growth simply included tax receipts as a share of GDP as a regressor. Plosser (1992) and Easterly and Rebelo (1993) both find a negative relationship between income taxes and growth. Yet both authors advise caution in interpreting the results as causal. The former points to the problem of collinearity among explanatory variables, whilst Easterly and Rebelo (1993) warn that their result was heavily dependent on the other covariates included.

As outlined above, there are various shortcomings with using tax receipts' share of GDP as the fiscal variable of interest. Easterly and Rebelo (1993) recognise that this can only be interpreted as the marginal rate of, for example, income tax, if income taxes were proportional. Martinez-Mongay (2000) argues that the main problem with using this method is that GDP itself is determined by the income from labour and capital. Furthermore, he notes that disaggregating individual tax flows into their share of GDP is also a poor proxy, as changes in these figures could be a result of either a change in the tax rate or a change in the relevant tax base's share of GDP, which might not necessarily be a result of tax law.

Kneller et al. (1999) claim that the majority of previous research ignores the fact that by focusing on just one side of the budget (i.e. on expenditure or taxation, but not both) results may be biased. They classify taxation as 'distortionary' or 'non-distortionary', and spending as 'productive' or 'non-productive', predicting that shifts towards the latter form of taxation (from distortionary) will have a positive effect on growth, as will shifts towards productive expenditure (from non-productive). ${ }^{5}$ The premise of this classification lies in their claim that the 'most relevant distortions' come from the incentives to invest rather than the labourleisure choice, which is the only facet affected by consumption taxes. With these four categories specified as explanatory variables, along with a balancing item (budget surplus), the authors proceed to omit the categories predicted to have a negligible effect on growth, namely the non-productive expenditure or non-distortionary taxes. The interpretation of results thus implies that a unit change in one of the included fiscal variables is necessarily 'offset by a unit change in the omitted category' (Kneller et al. 1999: 175). Results suggest that distortionary taxes do indeed retard GDP growth, whereas productive expenditure has the opposite effect. Estimates point to an increase in GDP growth of between 0.1 and 0.2 per cent following a 1 per cent decrease in distortionary taxation. Furthermore, they illustrate that ignoring one side of the budget can cause serious bias in the coefficient estimates, even flipping the sign of the coefficient on the variable in question. These results hold after rigorous robustness checks in Bleaney et al. (2001). In the sense that each of the tax and expenditure categories is expressed as a share of GDP, the results share the same limitations as previous studies. However these authors take great strides towards addressing any biases that might arise by also including expenditure as an independent variable. By and large, the result that increases in distortionary taxation, offset by decreases in nondistortionary revenue, are harmful to GDP growth is in line with the theoretical predictions of Barro (1990), Barro and Sala-i-Martin (1995) and Mendoza et al. (1997).

More accurate estimates of the marginal tax rate than can be provided by simply expressing revenue as a share of GDP are difficult to achieve. In order to fully and accurately estimate the effects of tax rates on GDP, one would require information not only on each of the marginal rates but also on the income distribution, which, for a large sample of countries over many years, is difficult to obtain or accurately estimate. Attempts have however been made: Lee and Gordon (2005) use the top corporate tax rate, finding a negative and significant relationship with per capita GDP growth. Coefficient estimates point to around a 0.6 percentage point increase in growth arising from a 10 per cent cut in the top corporation tax rate. Mendoza et al. (1994) construct their own 'effective tax rates' for consumption, labour and capital, which are computed as the ratio of the difference between the pre- and post-tax

They define distortionary taxes as taxes on income and profit, social security contributions, taxes on payroll and manpower, and property taxes. Non-distortionary taxes are therefore taxes on consumption. 
value of (consumption, labour or capital) income to the value of these incomes at pre-tax prices. ${ }^{6}$ Using the effective tax rates, Mendoza et al. (1997) test the theoretical model outlined in the same study, finding that a 10 percentage point decrease in labour (capital) income taxes leads to an increase in the investment rate of 1.8 (1.0) per cent. However no significant relationship was uncovered when using GDP growth as the dependent variable. Whilst these methods may be a closer fit to the relevant theoretical models, in the sense that they attempt to estimate the marginal tax rate, the data requirements pose a severe limitation to applicability, especially across a large panel of countries. This goes some way to explaining why such an approach has not been regularly replicated in the empirical literature.

An innovative approach that has been taken in more recent studies is to examine revenueneutral changes in the tax structure - that is, the effect on growth of changes in the tax structure, holding total tax receipts constant. By imposing the revenue-neutrality constraint, it is possible to 'avoid the difficulty of taking account of how any changes in aggregate revenue might be reflected in changes in public expenditure' (Arnold et al. 2011: F59). This approach is appealing in the sense that it allows the researcher to make use of datasets with rich information on the various components of taxation without requiring a similar level of coverage on the expenditure side. Arnold et al. (2011) find that a revenue-neutral increase in the share of income taxes (offset by a decrease in the share of consumption and property taxes) reduces GDP, measured in levels. Specifically, their results suggest that a percentage point increase in the share of income tax revenue leads to a reduction in the long-run level of GDP of between 0.25 and 1 per cent. Moreover they find that CIT have a stronger negative effect on GDP than PIT. Thus the authors find support for the theoretical predictions that consumption taxes are less distortive to growth than personal or corporate income taxes. Acosta-Ormaechea and Yoo (2012) extend the analysis of Arnold et al. (2011) to a broader panel of countries, and consider per capita GDP growth as opposed to GDP in levels. Similar results are uncovered: revenue-neutral increases in income taxes, offset by decreases in consumption and property taxes, lead to slower long-run economic growth to the tune of between 0.07 and 0.14 per cent for a 1 percentage point shift. Results hold for high- and middle-income countries, but are less robust for low-income countries.

Whilst there is some disparity over the best proxy for the marginal tax rate, it seems that results of studies in this field have reached similar conclusions. Kneller et al. (1999), Bleaney et al. (2001), Lee and Gordon (2005), Arnold et al. (2011) and Acosta-Ormaechea and Yoo (2012) all present evidence, using a variety of different proxies, that income taxes are more harmful for GDP or GDP growth than consumption taxes. Specifically, some of these papers separate the effects of PIT and CIT, arguing that the latter are the most harmful for growth. Returning to the questions posed at the start of this section, the existing evidence does suggest that taxes on corporate and personal income distort growth to a greater extent that those on consumption. By how much these taxes affect growth is wholly dependent on the proxy used as the tax variable in each case; the estimates discussed above however suggest only a modest impact of changes in tax rates or structure on economic growth. Turning to the question of where these effects have been seen, the vast majority of the aforementioned studies are consistent in that, to date, they have only considered OECD countries. To the best of our knowledge, the only papers to consider the effects amongst non-OECD (and specifically developing) countries have been those by Lee and Gordon (2005) and Acosta-Ormaechea and Yoo (2012). Whilst the former paper makes no attempt to distinguish between high- and low-income countries, Acosta-Ormaechea and Yoo (2012) find that their main results hold for high- and middle-, but not for low-income, countries. Many previous studies have likely confined analyses to OECD countries as a result of (for example) data availability; it is important in our context to understand the channels through

Lee and Gordon (2005) argue that the effective tax rates measure nothing more than an average tax on labour income, as opposed to the marginal rate. 
which fiscal policies can affect growth at all levels of development. The next section considers the characteristics of fiscal policies in developing countries.

\section{Fiscal policy and development}

Fiscal policy can, and indeed must, play an important role in the alleviation of poverty and the pursuit of development. For example, the UN Millennium Project (2005) estimates that lowincome countries may need to see their tax-GDP ratios increase by as much as 4 percentage points if the Millennium Development Goals (MDGs) are to be met. However the governments of developing countries face a very specific set of challenges with regard to the administration of fiscal policy. The primary concern is, of course, that of revenue mobilisation. It comes as little surprise that tax ratios are lower in developing, compared to advanced, economies; Table 1 highlights this. On average, tax revenue in low-income countries has been only around half as much as that in higher income categories over the last three decades.

Table 1 Tax revenue as \% of GDP7

\begin{tabular}{|llll|}
\hline & $\mathbf{1 9 8 0 - 1 9 8 9}$ & $\mathbf{1 9 9 0 - 1 9 9 9}$ & $\mathbf{2 0 0 0 - 2 0 0 9}$ \\
Low-income & 13.4 & 11.7 & 13.7 \\
Middle-income & 13.7 & 14.2 & 15.9 \\
High-income & 23.2 & 22.6 & 23.5 \\
OECD & 25.7 & 25.1 & 25.5 \\
\hline
\end{tabular}

Source: ITCD GRD (2014).

There are numerous explanations as to why the tax ratio remains low in developing countries:

i. Many still rely heavily on subsistence agriculture or the informal sector; according to the latest estimates from Schneider et al. (2010), the size of the average shadow economy in Sub-Saharan Africa was some 38.4 per cent of GDP, compared to an average of just 13.5 per cent in high-income OECD nations. ${ }^{8}$

ii. Tax avoidance by high-earning individuals is also a problem. The IMF (2011) promotes the view that vast revenue improvements can be realised by tackling this. ${ }^{9}$

iii. A further issue might arise where developing countries are locked in a 'race to the bottom' in order to attract investment from multinational corporations (OECD 2014).

iv. Low tax morale, perhaps as a result of citizens' low level of trust in public officials or administrations, also impedes compliance (OECD 2013; OECD 2014); one must only look at responses to the relevant questions in, for example, the Afrobarometer or World Values Survey, in order to see this illustrated.

\footnotetext{
$7 \quad$ We define 'tax revenue' here as the sum of taxes on income, profits and capital gains, trade taxes and consumption taxes. See below for an explanation of this choice.

8 The country in SSA with the largest informal sector in 2007 was Zimbabwe, at $62.7 \%$, whilst the smallest in the OECD was Switzerland, at $8.1 \%$.

$9 \quad$ This might, for example, take the form of legal loopholes or the use of tax havens.
} 
v. Inefficient, underdeveloped or under-resourced institutions, alongside unreliable communications infrastructure (such as the internet), can hinder the efficiency of tax administration.

vi. Widespread illiteracy and low population density (Reizman and Slemrod 1987).

vii. Vulnerability to shocks in commodity prices.

viii. Damage caused to the tax base and administrations by conflict (IMF 2011).

Tanzi and Zee's conclusion (2000: 300), that 'In developing countries, tax policy is often the art of the possible rather than the pursuit of the optimal', is thus quite fitting.

\section{Trends in the data}

As a result of the aforementioned issues, the tax structure in low-income countries differs significantly to that in developed nations. Figure 1 illustrates this, with a look at the direct to indirect tax mix. Our data is from the GRD of ICTD, which is compiled from sources such as OECD and the IMF. This dataset offers the most complete country coverage (specifically with regards to developing countries) for the longest time period available. For an in-depth description, including a full discussion of the inherent limitations of such a dataset, see Prichard et al. (2014). We choose to divide the data into four income categories (see Appendix 2 for country lists) for the three decades covered by our sample. Countries are classed as low-, middle- and high-income according to historic purchasing power parity (PPP) GDP per capita levels; we include a separate category for OECD countries. ${ }^{10}$ It is immediately clear that low- and middle-income countries have been quite heavily reliant on indirect taxes, which have, for the period of our sample, comprised between 70-75 per cent of total tax revenue. This is compared to high-income countries, where the split is roughly 50:50, and the sub-sample of OECD countries, which have collected around 55 per cent of revenue from direct taxes on average.

10 With data spanning 20 to 30 years, it would of course be unwise just to use the most recent GDP per capita figure in order to classify countries into low-, middle- or high-income. Using PPP GDP per capita, we divided the sample into three (according to the $33^{\text {rd }}$ and $66^{\text {th }}$ percentiles) for each year. Where a country moved groups, it was allocated to where it most often lay. As such we mirror the approach taken by Acosta-Ormaechea and Yoo (2012), although ultimately our classifications differ somewhat. 
Figure 1 Direct-indirect split by decade and income group

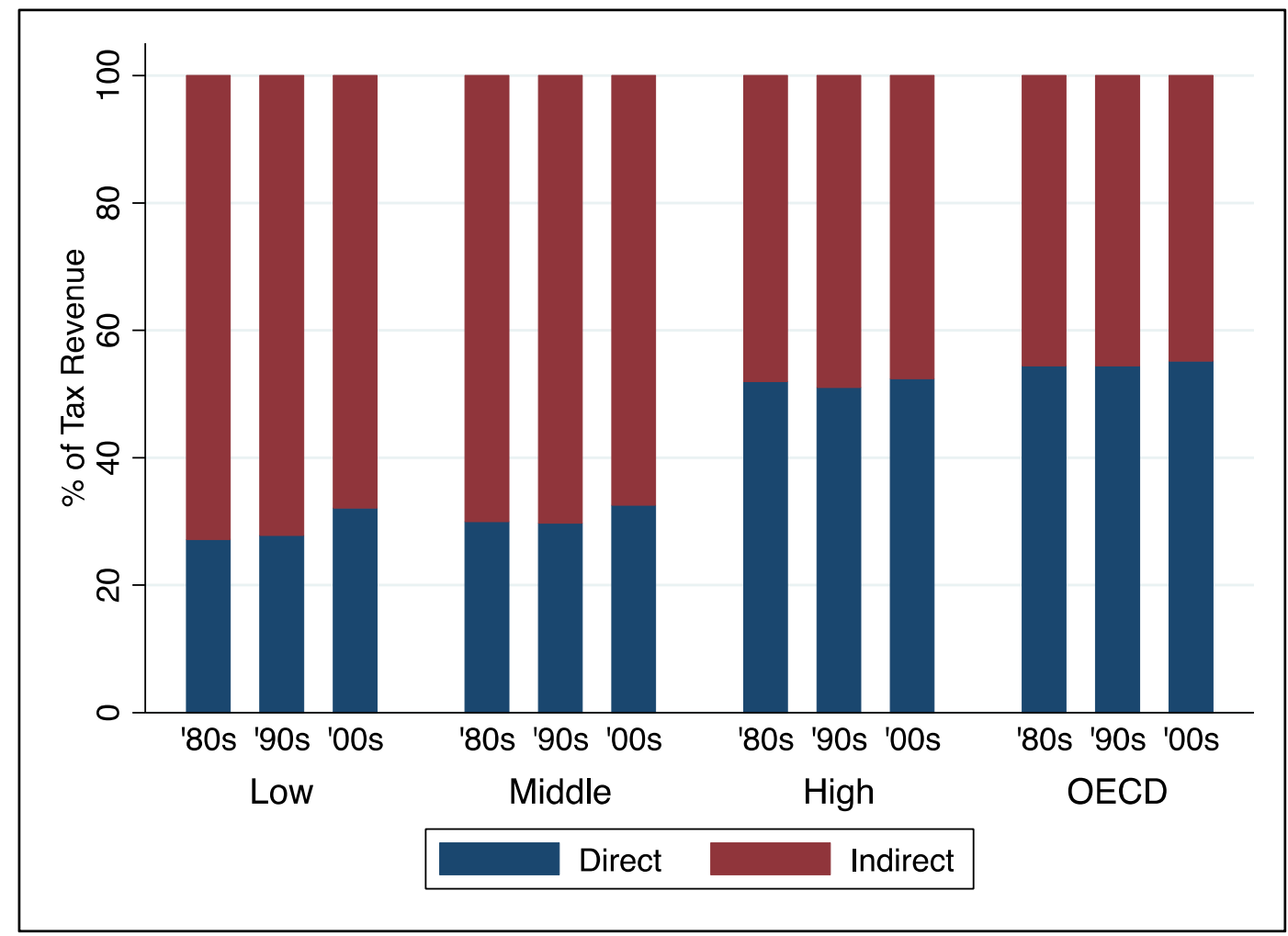

Source: ICTD GRD (2014).

Developing countries place a relatively heavy reliance on trade taxes such as import tariffs. Whilst this might be a result of protectionist policies, it is also true that trade taxes are cheaper and easier to collect than income or consumption taxes: tariffs can be collected at ports or border crossings, and thus the administration of such charges is more easily organised and collected than that of, say, an income tax on workers spread across the country. Yet too heavy a dependence on trade taxes has well-understood growth implications: the efficiency gains from exposure to international competition can greatly enhance the long-run growth potential not only for specific industries, but the economy as a whole. Trade liberalisation does however place significant revenue constraints on many lowincome countries, which might find limited scope to meet these needs by increasing standard consumption tax rates (IMF 2011). Furthermore, income taxes might not be an effective means to raise revenue, due to the fact that the majority of citizens may not actually earn enough to even be eligible to pay (Thirlwall 2006).

Figures 2a-2d disaggregate tax revenue into three categories: direct taxes, taxes on goods and services, and taxes on international trade and transactions. The category 'direct taxes' includes personal income taxes, taxes on corporate profits and, where available, property taxes. We choose to concentrate on the aforementioned three categories due to relative consistency and comparability of the data across countries and sources. 
Figure 2a Tax structure 1980-2009: low-income countries

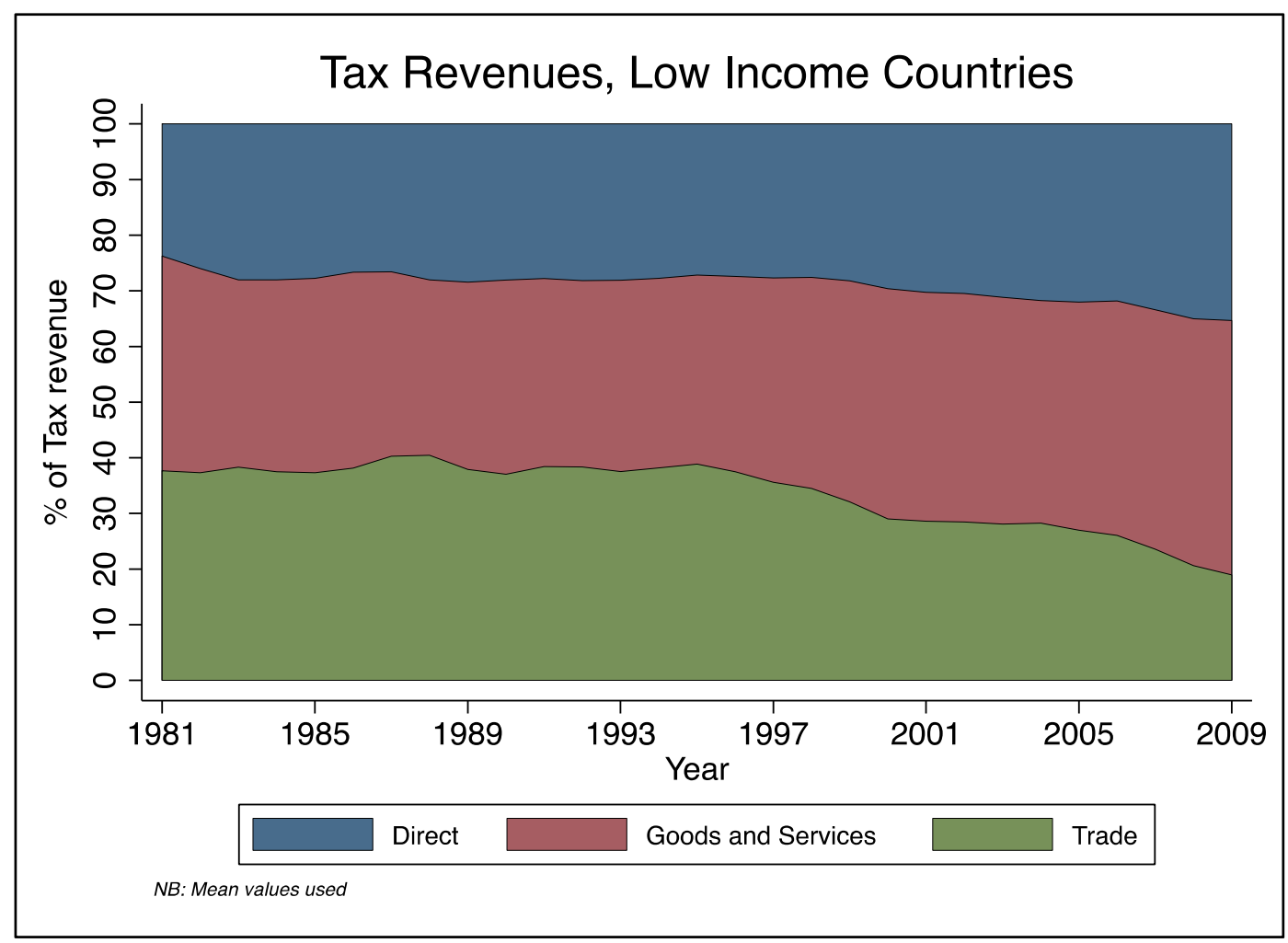

Source: ICTD GRD (2014)

Figure 2b: Tax structure 1980-2009: middle-income countries

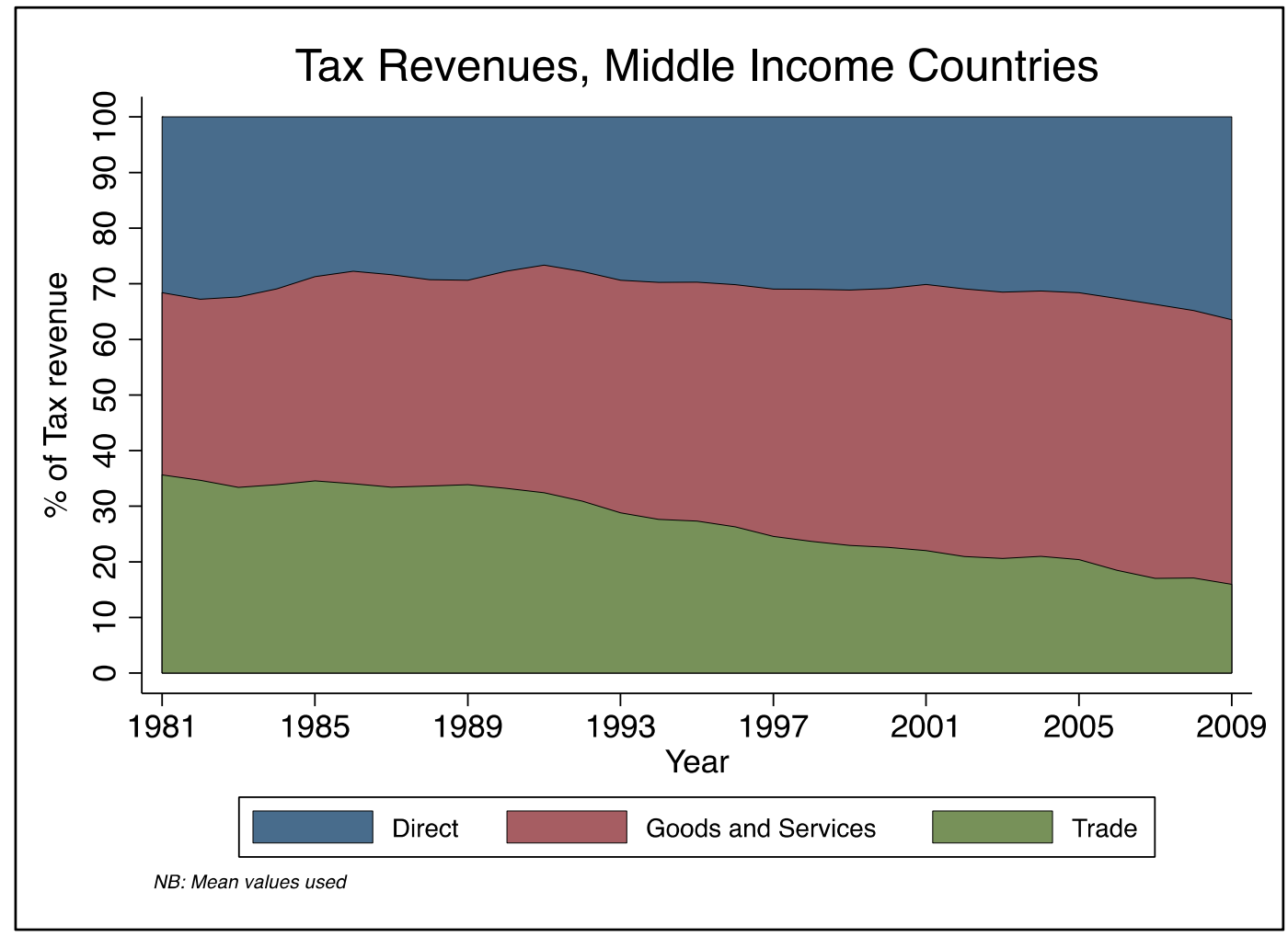

Source: ICTD GRD (2014). 
Figure 2c Tax structure 1980-2009: high-income countries

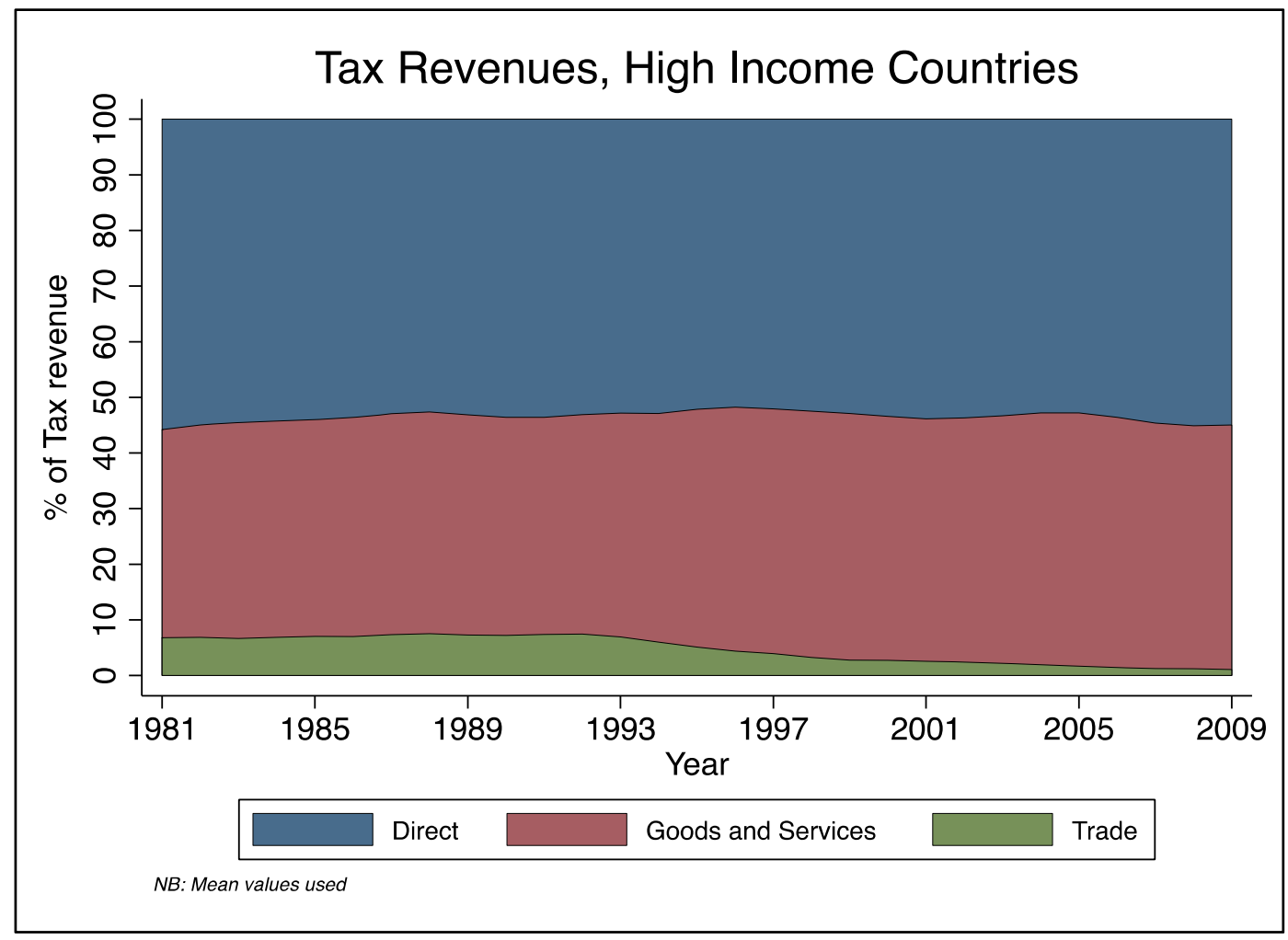

Source: ICTD GRD (2014).

Figure 2d Tax structure 1980-2009: OECD countries

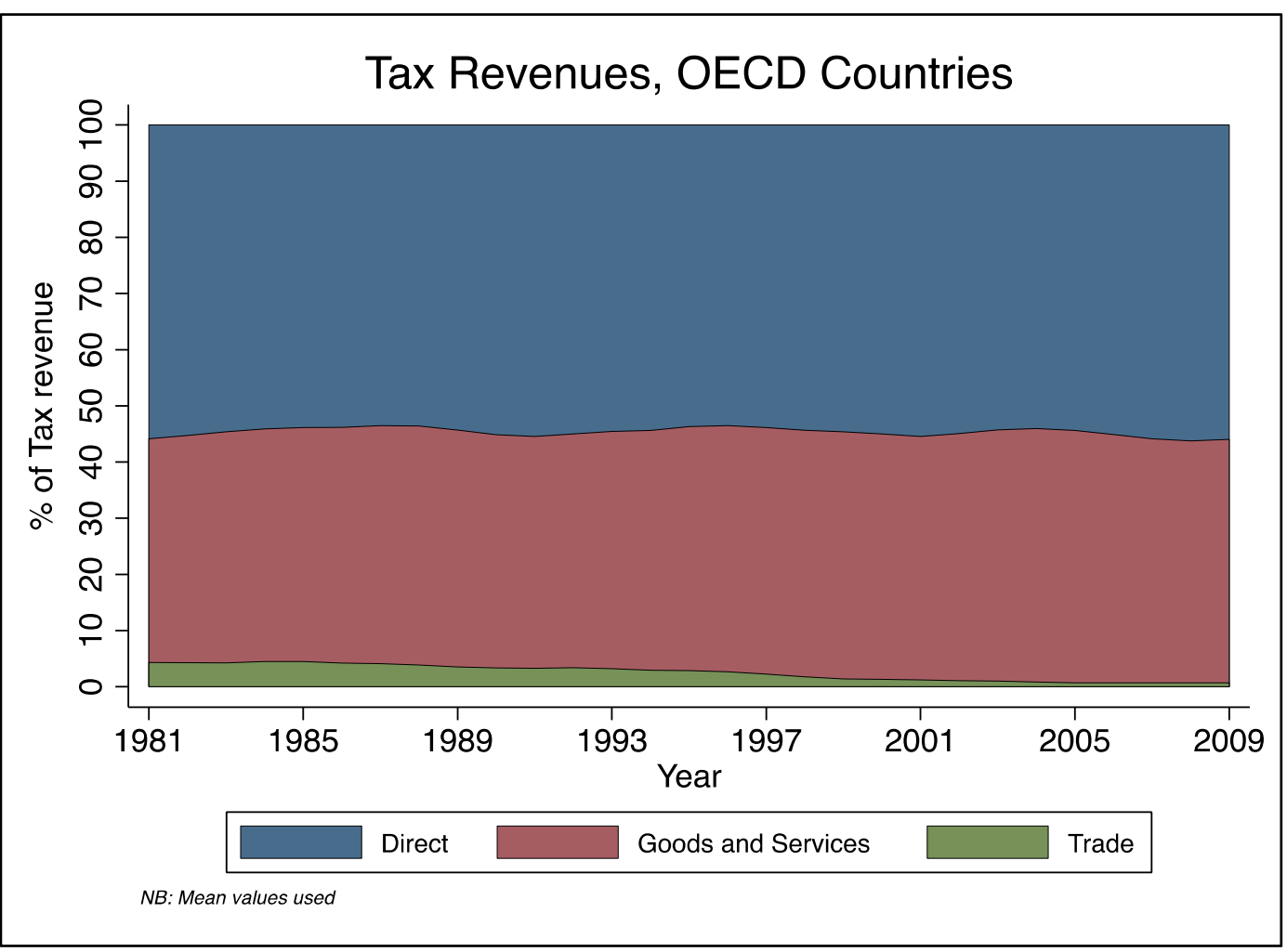

Source: ICTD GRD (2014) 
What is immediately clear from Figure $2 a$ is the initially high reliance on trade taxes in lowincome countries. In 1981, this makes up on average just below 40 per cent of total tax revenue. The general trend is away from such tariffs towards taxes on goods and services, such as VAT. Indeed, by 2009, trade taxes make up just 20 per cent of total revenue; across the same time period, taxes on goods and services increase from around 33 per cent to about 45 per cent of total revenue by the end of the period in question. This is certainly a reflection of the on-going global trend towards removing trade barriers, and also of the IMF recommendations that seek to encourage a move away from trade taxes towards taxes on goods and services. Taxes on income, profits and capital gains are relatively steady throughout the period, beginning at between 25 to 30 per cent of total revenue, with greater increases occurring in the 2000 s seeing this figure grow to around 35 per cent. A similar trend can be seen in those countries classed as middle-income (Figure 2b), where trade taxes initially comprise around 35 per cent of total revenue, falling to between 15 and 20 per cent in the 2000s. The shift towards consumption taxes is more marked for this sample of countries: revenue for this category increases from around 35 to almost 50 per cent on average during the period in question. Direct taxes comprise a fairly constant 30 to 35 per cent of total revenue. Figure $2 c$ displays the various revenue streams for high-income countries: such countries have clearly not been as reliant on trade taxes as others (they comprise around 6-7 per cent of total revenue in the 1980s, but this drops away to just 1 per cent by the end of the period in question), and have instead focused on consumption and income taxes to a much greater extent. High-income countries, perhaps as a result of more efficient tax collection and administration, are typically more reliant on direct taxes such as capital gains, corporation, or income taxes. What is more, the relative stability of the tax structure in high-income countries is noticeable. Many are members of free trade areas such as the North American Free Trade Agreement (NAFTA) or the European Union (EU), and as such the replacement of trade barriers with consumption taxes may well have occurred before the timeframe in question in this study. It is noticeable that almost all the changes in structure for high-income countries have seen a shift from trade to consumption taxes; direct taxes comprise between 50 and 55 per cent of revenue for the period. ${ }^{11}$ The trends in Figure $2 \mathrm{~d}$, for OECD countries only, are similar, although trade taxes comprise a marginally lower portion of revenue in the 1980s.

In Figures $3 \mathrm{a}$ and $3 \mathrm{~b}$ we subdivide direct taxes into personal and corporate income taxes (PIT and CIT respectively). ${ }^{12} \mathrm{~A}$ couple of limitations apply when disaggregating the data this far. Firstly, the sample size is reduced to around sixty-five countries per year; this loss of observations is felt most strongly pre-1990, where, after classing countries according to income group, the sample becomes too small to provide meaningful statistics. As such it is more insightful to only present the data from 1990 onwards, and to group low- and middleincome countries together. ${ }^{13}$ The insights are, however, clear: all countries in the sample rely on CIT to a similar extent, between 10 and 15 per cent on average. Interestingly, however, we see that PIT constitute a much greater portion of revenue in high-income countries (35-40 per cent for the period), compared to low- or middle-income (around 10-11 per cent). This is likely to be a reflection of some of the aforementioned issues: low incomes, large shadow economies and low population density make raising revenue from PIT difficult.

\footnotetext{
11 NB. We choose to omit Bahrain and Gabon from the high-income sample. These countries had a disproportionately high level of trade revenue (50 and 69 per cent respectively).

12 The sum of these two differs somewhat from the 'direct' category used in Figures 2a-d. The corresponding residual can thus be apportioned to property or 'other' direct taxes.

13 We do not show the 'OECD countries only' graph here in the interests of space, but given the substantial overlap with the high-income category, it brings little further insight.
} 
Figure 3a: Tax structure, including subdivisions of income tax 1990-2009: low- and middle-income countries

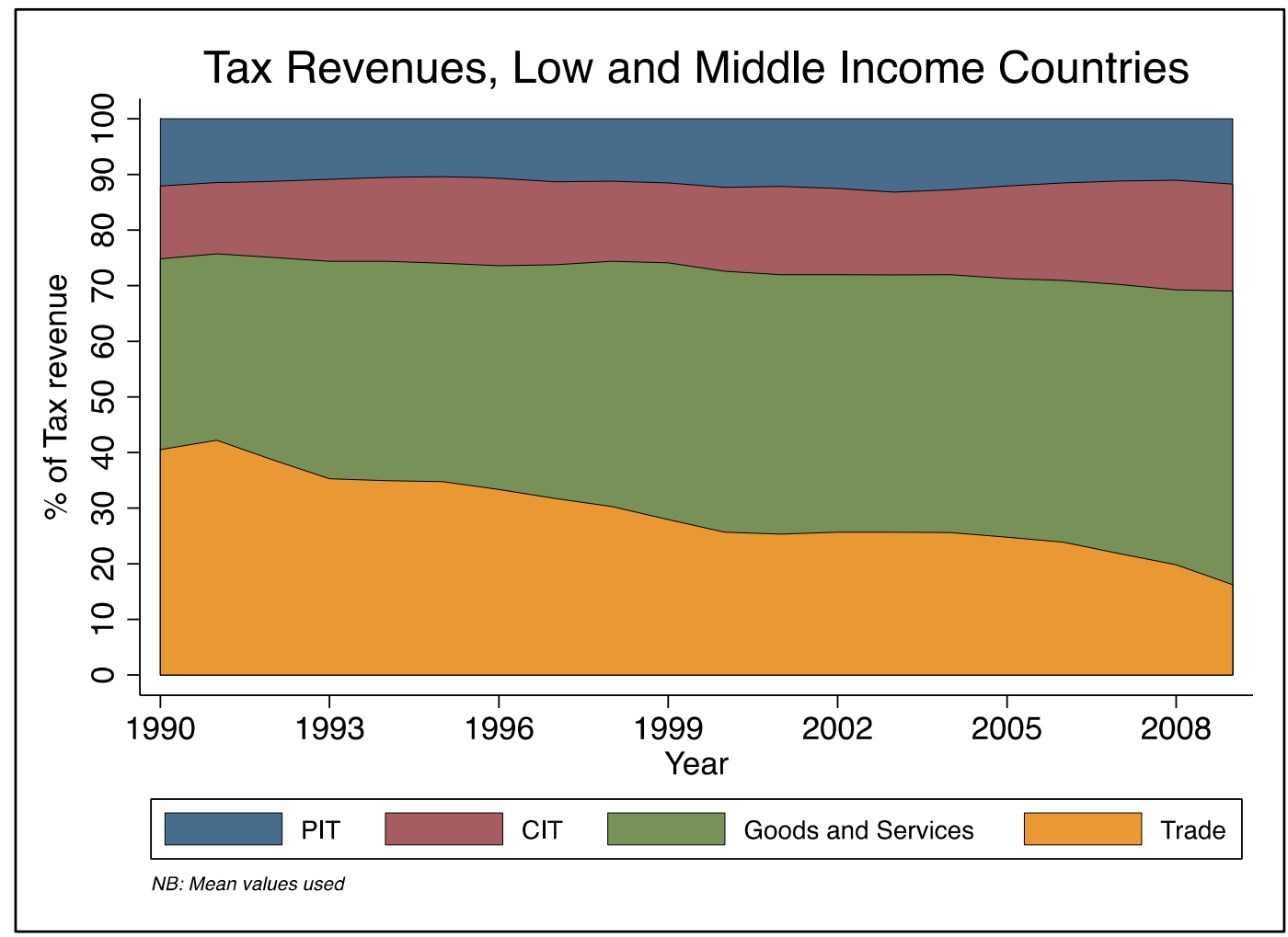

Source: ICTD GRD (2014)

Figure 3b Tax structure, including subdivisions of income tax 1990-2009: high-income countries

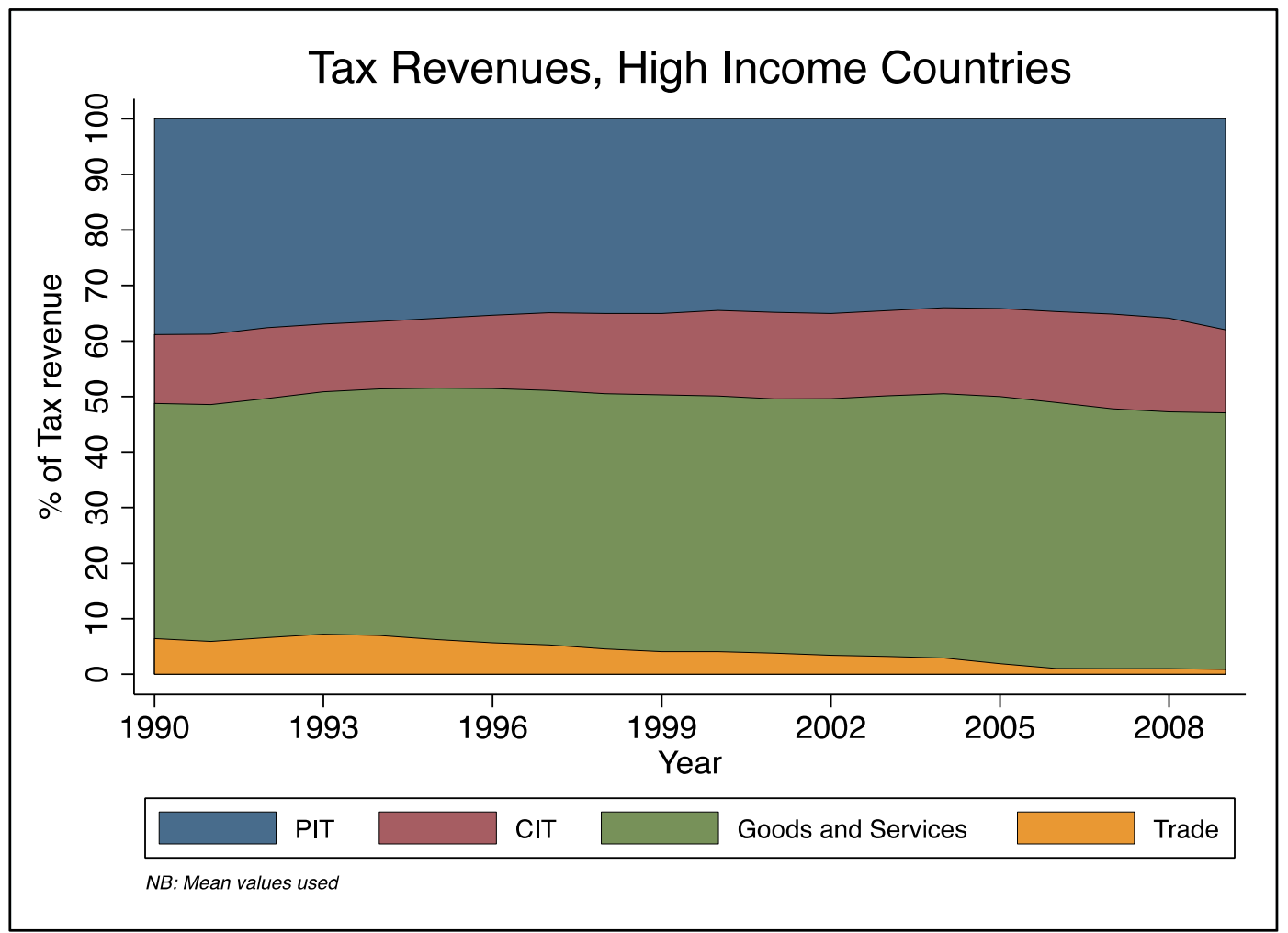

Source: ICTD GRD (2014) 
Thus, much of the reform that has taken place in low- and middle-income countries over recent decades has seen a move away from reliance on trade taxes towards the introduction of consumption taxes such as VAT, as opposed to increases in income or profit taxes. Indeed, this is certainly a change that has been encouraged by the IMF (2011), who describe VAT as 'the standard policy prescription' for countries battling the revenue challenges that come from trade liberalisation. Specifically, they note that VAT is able to raise revenue in a way that is less distortive to economic activity than alternatives, whilst also having the advantage of being simpler to administer and comply with than, for example, an income tax. ${ }^{14}$ High-income and OECD countries have, at least for the duration of the sample considered, been more heavily reliant on direct taxes. The next section discusses the econometric methodology followed in order to estimate the effects of tax composition on GDP growth.

\section{Econometric approach}

This section outlines our empirical investigation into the impact of the tax structure on economic growth. In doing so, we follow the approach taken by much of the recent taxgrowth literature (inter alios Arnold et al. 2011; Acosta-Ormaechea and Yoo 2012) by considering revenue-neutral changes in the tax structure, whilst controlling for the overall level of tax as a proportion of GDP. Examining revenue-neutral shifts in tax structure allows us to consider the effects of changes in tax policy on growth, without the need to take account of how changes in tax policy might be a result of changes in government expenditure (Arnold et al. 2011). Thus it avoids the requirement of similar levels of data on public expenditure as on tax revenue. Furthermore, given limitations on the availability of data on tax rates, we believe this approach represents the best available proxy for the marginal tax rate which is considered in the relevant theoretical models. We disaggregate tax revenue into different combinations of the categories used in Section 4. Thus interpreting the effect of, for example, a percentage point increase in the share of total revenue for the included category (categories), implies a percentage point reduction in the share of total revenue from the omitted category (categories).

The basic model estimated is as follows

$\Delta y_{i t}=a_{i t}+\beta s_{i t}^{k}+\theta h_{i t}+\gamma n_{i t}+\varphi \boldsymbol{T}_{i t}+u_{i t}$

where $\Delta y_{i t}$ is annual growth in (log) GDP per capita, $s_{i t}^{k}$ is (log) investment in physical capital, $k$, as a share of GDP, $h_{i t}$ is (log) average years of schooling, ${ }^{15} n_{i t}$ is growth in the (log) working age population and $\boldsymbol{T}_{i t}$ is a vector of tax variables, which includes tax receipts as a share of GDP and $n-1$ tax revenue categories which are expressed as a share of total revenue. Subscripts $i$ and $t$ denote countries and years respectively. Data for GDP, investment (fixed capital formation) and population come from the World Bank's databank. Education data comes from the Barro and Lee (2013) education dataset. Finally, the tax variables are from the GRD (Prichard et al. 2014). A full set of summary statistics is listed in Appendix 1. These covariates are included as we wish to follow the relevant endogenous

14 Specifically, the IMF (2011) advocates that broadening the base of VAT would bring more significant revenue effects than increasing existing rates.

15 The Barro and Lee (2013) data is only presented for 5-year intervals. We therefore use linear interpolation in order to obtain annual data. This approach is also taken in, for example, Acosta-Ormaechea and Yoo (2012). One could alternatively restrict the series to be constant for five-year intervals, but this would imply that improvements/ deteriorations in the human capital stock occur only every five years, which would be an inappropriate assumption. It is of course a strong assumption that the variable evolves according to a linear process in 5-year cycles, however it was rarely the case in the raw dataset that a country experienced both improvements and deteriorations in the timeframe considered. Thus we feel that the approach taken is the most accessible and appropriate. 
growth models discussed above closely. Furthermore, this ensures comparability with related studies such as Acosta-Ormaechea and Yoo (2012).

The choice of empirical approach taken with panel time series data, such as we have, results from certain assumptions made regarding the data. We present a range of results from estimators that impose different parameter restrictions, some of which account for the effects of common factors. The validity of the assumptions made can then be tested using a number of residual diagnostic tests. ${ }^{16}$

In working with a large $N$, large $T$ dataset, it is important to account for the fact that some unobserved common effects are likely to be correlated with the regressors or driving the error process for some (if not all) panel units. In a growth regression, such cross-sectional dependencies (CSD) or common effects could take the form of, for example, a global downturn, spillover effects, conflicts, etc. In reality it is not possible to isolate the effects themselves; there are likely to be many, affecting different countries to varying degrees. This issue can be addressed in three ways: (i) via a spatial approach (where a priori knowledge of the spatial weight matrix is required - for example, distance between countries, neighbourhood effects); (ii) explicit modelling of the CSD; or (iii) a residual multi-factor approach. The spatial approach does not allow for parameter heterogeneity, and to model the CSD would require knowledge of all the latent factors for a large $N$, large $T$ panel is unrealistic; there could feasibly be any number of such effects at play. It is however possible to account for such spill-overs by augmenting the growth equation with cross-sectional averages of the dependent and independent variables; this is the procedure followed for the Common Correlated Effects Pooled (CCEP) and Common Correlated Effects Mean Group $(\mathrm{CMG})$ regressions below. ${ }^{17}$

At one end of the scale, the Pooled Ordinary Least Squares (POLS) and Fixed Effects (FE) estimators restrict slope coefficients to be equal across panel units $\left(\beta_{i}=\beta ; \theta_{i}=\theta ; \gamma_{i}=\right.$ $\left.\gamma ; \varphi_{i}=\varphi, \forall i\right)$, whilst also assuming that the effect of CSD is the same in all countries. An intermediate estimator, the CCEP estimator, interacts country dummies with cross-sectional averages of the dependent and independent variables in order to allow for a heterogeneous effect of CSD, whilst still imposing the restriction that $\beta_{i}=\beta ; \theta_{i}=\theta ; \gamma_{i}=\gamma ; \varphi_{i}=\varphi \forall$. Intuitively, imposing parameter homogeneity in such a varied sample of countries seems like a strong assumption. Even if, in the very long run, countries do grow in a similar manner, our dataset spans at most only thirty years; this represents a mere snapshot in time, capturing a large cross section of countries at widely varying stages of development. As such it is desirable to examine the results from more flexible specifications. The Mean Group (MG) estimator allows for full parameter heterogeneity, and the CMG estimator is augmented with cross-sectional averages of the dependent and independent variables, allowing for a heterogeneous impact of unobservable common factors.

The Mean Group (MG) estimator proposed by Pesaran and Smith (1995), estimates (via OLS) the equation

$y_{i t}=a_{i}+\beta_{i} x_{i t}+\varepsilon_{i t}, \quad \varepsilon_{i t} \sim i i d\left(0, \sigma_{i}^{2}\right)$

individually for each cross-sectional unit, and reports an average. Thus it allows for full parameter heterogeneity. The CMG estimator, proposed by Pesaran (2006), augments the

16 The emerging panel time series literature offers a number of papers that have followed a similar approach in justifying the choice of estimator. For a more detailed discussion, see, for example, Eberhardt and Teal (2011) or Eberhardt et al. (2013).

17 All estimations were carried out in STATA 12. We used the user written command xtmg (Eberhardt 2012) for the MG and CMG regressions, and applied the approach outlined in Eberhardt (2011) in order to estimate the CCEP regressions. Tests for cross-sectional dependence were carried out using the xtcd (Eberhardt 2011) and xtcsd (De Hoyos and Sarafidis 2006) commands. 
MG regression [2] with cross-sectional averages of the dependent and independent variables as follows. ${ }^{18}$

$y_{i t}=a_{i}+\beta_{i} x_{i t}+c_{1} \bar{y}_{t}+c_{2} \bar{x}_{t}+\varepsilon_{i t}, \quad \varepsilon_{i t} \sim \operatorname{iid}\left(0, \sigma_{i}^{2}\right)$

This estimator has been found to be robust in the presence of various different latent factor structures (e.g. combinations of unobserved factors that drive the error process, the regressors, or combinations of both). Monte Carlo simulations in Coakley et al. (2006) found the CCEMG estimator to be the least biased and most efficient from a menu of ten alternative estimators, even in relatively small samples ( $N=30, T=100 ; N=20, T=30)$; Pesaran (2006) shows the performance of the CCEMG to be asymptotically unbiased, for both fixed $T$ and $T \rightarrow \infty$. Indeed he found the estimator to be satisfactorily unbiased in samples as small as $T=20$. Furthermore, MG estimation has been proven capable of dealing with both $\mathrm{I}(0)$ and I(1) series, including the unobserved effects.

\section{Results}

\subsection{Full sample}

This section presents results from various estimations of equation [1]. Tables $2 a, 3 a$ and $4 a$ show results for those regressions where the coefficients are constrained to be equal across panel units (namely, the POLS, FE and CCEP estimators), whilst Tables 2b, 3b and 4b show results for the same regressions carried out using the MG and CMG techniques. Time dummies or trends are included where indicated. ${ }^{19}$ Whilst the full dataset contains information on tax revenue for around 190 countries, our sample is reduced in various ways. Firstly, we restrict the empirical analyses to those countries where $T \geq 20$. Secondly, there are various observations where tax accounting was inconsistent with surrounding years or of questionable quality, and so these observations have been excluded (see Prichard et al. (2014) for a thorough discussion of the limitations of the dataset). Finally, the availability and completeness of the control variables included differs from country to country. As such we are left with an unbalanced panel with $N$ between 100 and 110; $T$ is, on average, around 23.

Turning to the results, in Table $2 a$ we omit consumption and trade taxes. The revenueneutrality constraint implies that a point increase in direct taxes is offset by a point reduction in indirect taxes (consumption and trade). The estimates suggest that a percentage point increase in direct taxes has a negative and significant impact on the GDP growth rate. Depending on the specification, the associated reduction in GDP growth lies somewhere between 0.023 per cent and 0.1 per cent. Turning to Table $2 \mathrm{~b}$, the MG and CMG results suggest a similar relationship. The CMG results in column 4 suggest that the reduction in the GDP growth rate following a point increase in share of direct taxes is 0.13 per cent. We reject the $H_{0}$ of cross-sectionally independent residuals in columns 1 and 2, but fail to reject in 3 and 4. Therefore the latter results are preferred. Furthermore, the Root Mean Squared Error (RMSE) implies that the models in columns 3 and 4 are a superior fit. ${ }^{20}$

18 The cross-sectional averages themselves cannot be interpreted, so it is not possible to isolate the impact of any common effect on growth.

19 Often, in an OLS or FE framework, data is averaged over 5-year time periods in order to capture business cycle effects. Whilst we do not follow this particular approach, our results are robust to the inclusion of 5-year period dummies.

Non-stationary variables and/or residuals are often pervasive in panel time series contexts. Due to the unbalanced nature of our panel we have, at this stage, been unable to perform the necessary tests for stationarity of residuals. It is thus safest to assume that the problem exists and to treat the MG and CMG as the preferred specifications; these estimators have been shown capable of dealing with such issues. Furthermore, the tests for cross-sectional dependence also require a strongly balanced panel. The statistics shown were computed from identical models restricted to only those countries with more than 25 years of observations. In all cases the qualitative result of the regressions were the same. 
Table 2a Full sample, pooled specifications, indirect taxes omitted

\begin{tabular}{|c|c|c|c|c|}
\hline Pooled specifications & (1) & $(2)$ & (3) & (4) \\
\hline & POLS & FE & CCEP & CCEP \\
\hline Dependent variable & \multicolumn{4}{|c|}{$\Delta$ Log GDP per capita } \\
\hline Physical capital & $\begin{array}{l}0.032^{* * *} \\
(0.003)\end{array}$ & $\begin{array}{l}0.035^{\star \star *} \\
(0.006)\end{array}$ & $\begin{array}{l}0.034^{* * *} \\
(0.005)\end{array}$ & $\begin{array}{l}0.033^{\star * *} \\
(0.005)\end{array}$ \\
\hline Human capital & $\begin{array}{l}0.004 \\
(0.003)\end{array}$ & $\begin{array}{l}0.023^{\star *} \\
(0.010)\end{array}$ & $\begin{array}{l}0.058 \\
(0.039)\end{array}$ & $\begin{array}{l}0.034 \\
(0.043)\end{array}$ \\
\hline Population growth & $\begin{array}{l}-0.237 \\
(0.162)\end{array}$ & $\begin{array}{l}-0.006 \\
(0.230)\end{array}$ & $\begin{array}{l}-0.272 \\
(0.182)\end{array}$ & $\begin{array}{l}-0.232 \\
(0.183)\end{array}$ \\
\hline Tax revenue & $\begin{array}{l}0.00011 \\
(0.00015)\end{array}$ & $\begin{array}{l}0.017^{*} \\
(0.010)\end{array}$ & $\begin{array}{l}0.032^{* * *} \\
(0.008)\end{array}$ & $\begin{array}{l}0.032^{* * *} \\
(0.009)\end{array}$ \\
\hline \multicolumn{5}{|l|}{ Direct taxes } \\
\hline $\begin{array}{l}\text { Taxes on income, profits } \\
\& \text { capital gains }\end{array}$ & $\begin{array}{l}-0.00023^{* * *} \\
(0.00006)\end{array}$ & $\begin{array}{l}-0.0006^{\star * *} \\
(0.0002)\end{array}$ & $\begin{array}{l}-0.001^{* * *} \\
(0.0003)\end{array}$ & $\begin{array}{l}-0.001^{* * *} \\
(0.0003)\end{array}$ \\
\hline Constant & $\begin{array}{l}-0.07^{* * *} \\
(0.014)\end{array}$ & $\begin{array}{l}-0.154^{* * *} \\
(0.035)\end{array}$ & $\begin{array}{l}-0.373^{\star \star *} \\
(0.116)\end{array}$ & $\begin{array}{l}15.548 \\
(36.569)\end{array}$ \\
\hline$N$ & 2376 & 2376 & 2422 & 2422 \\
\hline No. of countries & 108 & 108 & 109 & 109 \\
\hline CD test ( $p$ value) & - & - & - & - \\
\hline Omitted category & \multicolumn{4}{|c|}{ Trade and consumption taxes (indirect) } \\
\hline Trend & - & - & - & - \\
\hline Year dummies & Yes & Yes & - & Yes \\
\hline RMSE & 0.039 & 0.038 & - & - \\
\hline${ }^{*} p<0.1 ;{ }^{* *} p<0.05 ;{ }^{* * *} p<0.01$ & \multicolumn{4}{|c|}{ Standard errors in parentheses } \\
\hline
\end{tabular}

Source: ICTD GRD (2014) 
Table 2b Full sample, heterogeneous specifications, indirect taxes omitted

\begin{tabular}{|c|c|c|c|c|}
\hline Heterogeneous specifications & (1) & $(2)$ & $(3)$ & $(4)$ \\
\hline & MG & MG & CMG & CMG \\
\hline Dependent variable & \multicolumn{4}{|c|}{$\Delta$ Log GDP per capita } \\
\hline Physical capital & $\begin{array}{l}0.066^{* * *} \\
(0.009)\end{array}$ & $\begin{array}{l}0.066^{* * *} \\
(0.012)\end{array}$ & $\begin{array}{l}0.061^{* * *} \\
(0.010)\end{array}$ & $\begin{array}{l}0.072^{* * *} \\
(0.012)\end{array}$ \\
\hline Human capital & $\begin{array}{l}0.080^{* * *} \\
(0.024)\end{array}$ & $\begin{array}{l}0.127 \\
(0.115)\end{array}$ & $\begin{array}{l}0.042 \\
(0.069)\end{array}$ & $\begin{array}{l}0.126 \\
(0.148)\end{array}$ \\
\hline Population growth & $\begin{array}{l}-0.376 \\
(0.342)\end{array}$ & $\begin{array}{l}-0.681 \\
(0.500)\end{array}$ & $\begin{array}{l}-0.596 \\
(0.483)\end{array}$ & $\begin{array}{l}0.110 \\
(0.534)\end{array}$ \\
\hline Tax revenue & $\begin{array}{l}0.014 \\
(0.016)\end{array}$ & $\begin{array}{l}0.023 \\
(0.173)\end{array}$ & $\begin{array}{l}0.024 \\
(0.019)^{\star}\end{array}$ & $\begin{array}{l}0.020 \\
(0.180)\end{array}$ \\
\hline \multicolumn{5}{|l|}{ Direct taxes } \\
\hline $\begin{array}{l}\text { Taxes on income, profits } \\
\text { and capital gains }\end{array}$ & $\begin{array}{l}-0.0017^{* \star *} \\
(0.00034)\end{array}$ & $\begin{array}{l}-0.0016^{* * \star} \\
(0.0004)\end{array}$ & $\begin{array}{l}-0.0016^{* * *} \\
(0.0005)\end{array}$ & $\begin{array}{l}-0.0013^{\star * *} \\
(0.0004)\end{array}$ \\
\hline Constant & $\begin{array}{l}-0.349^{* * *} \\
(0.076)\end{array}$ & $\begin{array}{l}-0.322^{*} \\
(0.179)\end{array}$ & $\begin{array}{l}-0.325^{\star} \\
(0.196)\end{array}$ & $\begin{array}{l}-0.167 \\
(0.334)\end{array}$ \\
\hline$N$ & 2357 & 2357 & 2357 & 2357 \\
\hline No. of countries & 103 & 103 & 103 & 103 \\
\hline CD test ( $p$ value) & 0.00 & 0.00 & 0.55 & 0.55 \\
\hline Omitted category & \multicolumn{4}{|c|}{ Trade and consumption taxes (indirect) } \\
\hline Trend & - & Yes & - & Yes \\
\hline Year dummies & - & - & - & - \\
\hline RMSE & 0.028 & 0.027 & 0.021 & 0.019 \\
\hline${ }^{*} p<0.1 ;{ }^{* *} p<0.05 ;{ }^{* * *} p<0.01$ & \multicolumn{4}{|c|}{ Standard errors in parentheses } \\
\hline
\end{tabular}

Source: ICTD GRD (2014)

In Tables $3 a$ and $3 b$, we omit trade taxes. In many ways this is perhaps the most interesting specification: one of the primary advantages of the ICTD dataset is the developing country coverage, and it is in these nations that the greatest shift away from trade taxes has been seen. This was highlighted in Figure 2 above. We again see more favourable CD test and RMSE statistics for the CMG estimations. From column 4, the coefficient attached to direct taxes' share implies that a percentage point decrease in trade taxes leads to a 0.27 per cent decrease in the rate of per capita GDP growth. Interestingly, in some specifications there is weak evidence (i.e. at the 10 per cent level) of negative implications for GDP growth of an increase in consumption taxes offset by a decrease in trade taxes (column 2, Table 3b). However this result is not robust to having taken account of cross-sectional dependencies, and as such we would urge caution when drawing conclusions. 
Table 3a Full sample, pooled specifications, trade taxes omitted

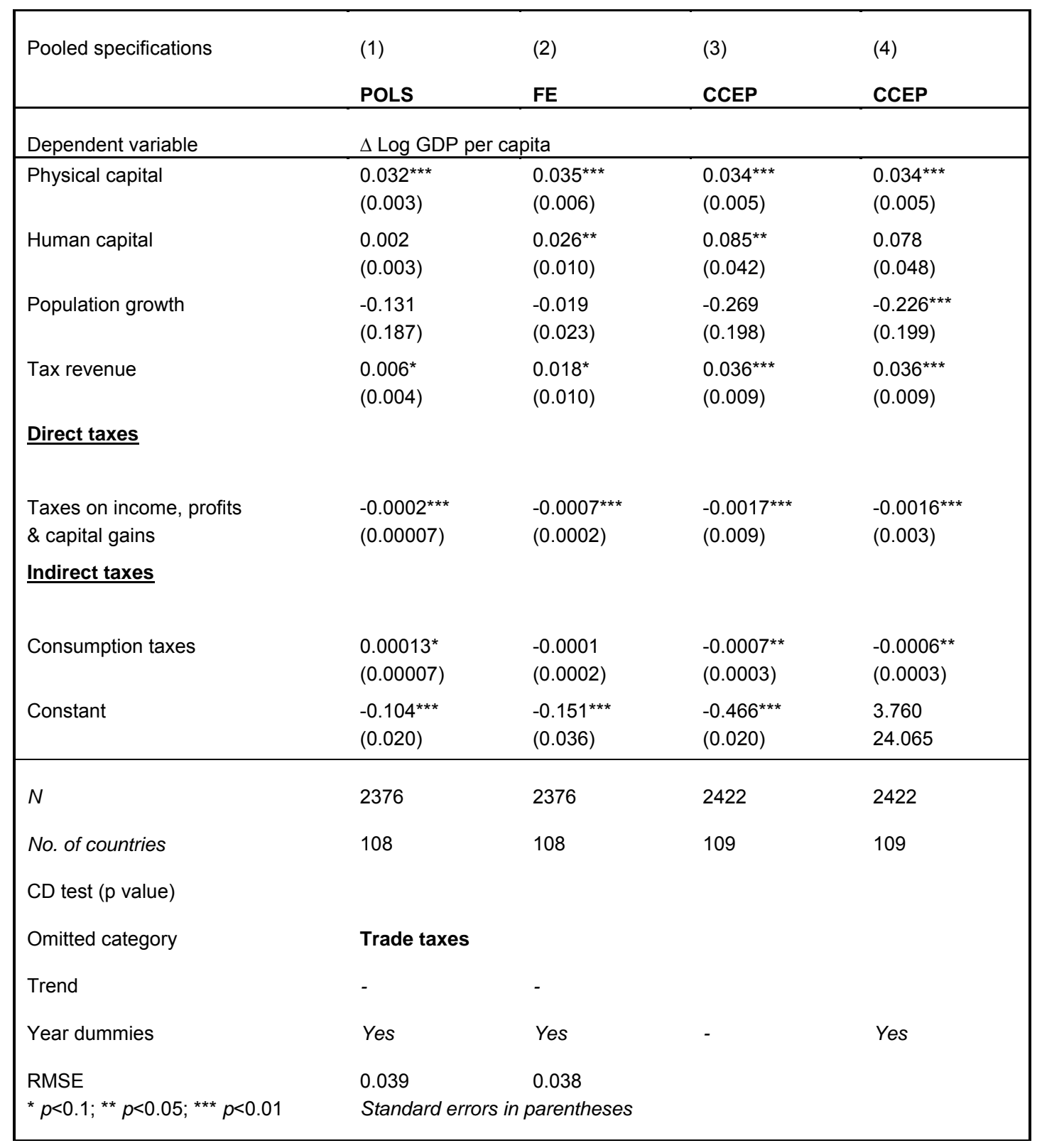

Source: ICTD GRD (2014). 
Table 3b Full sample, heterogeneous specifications, trade taxes omitted

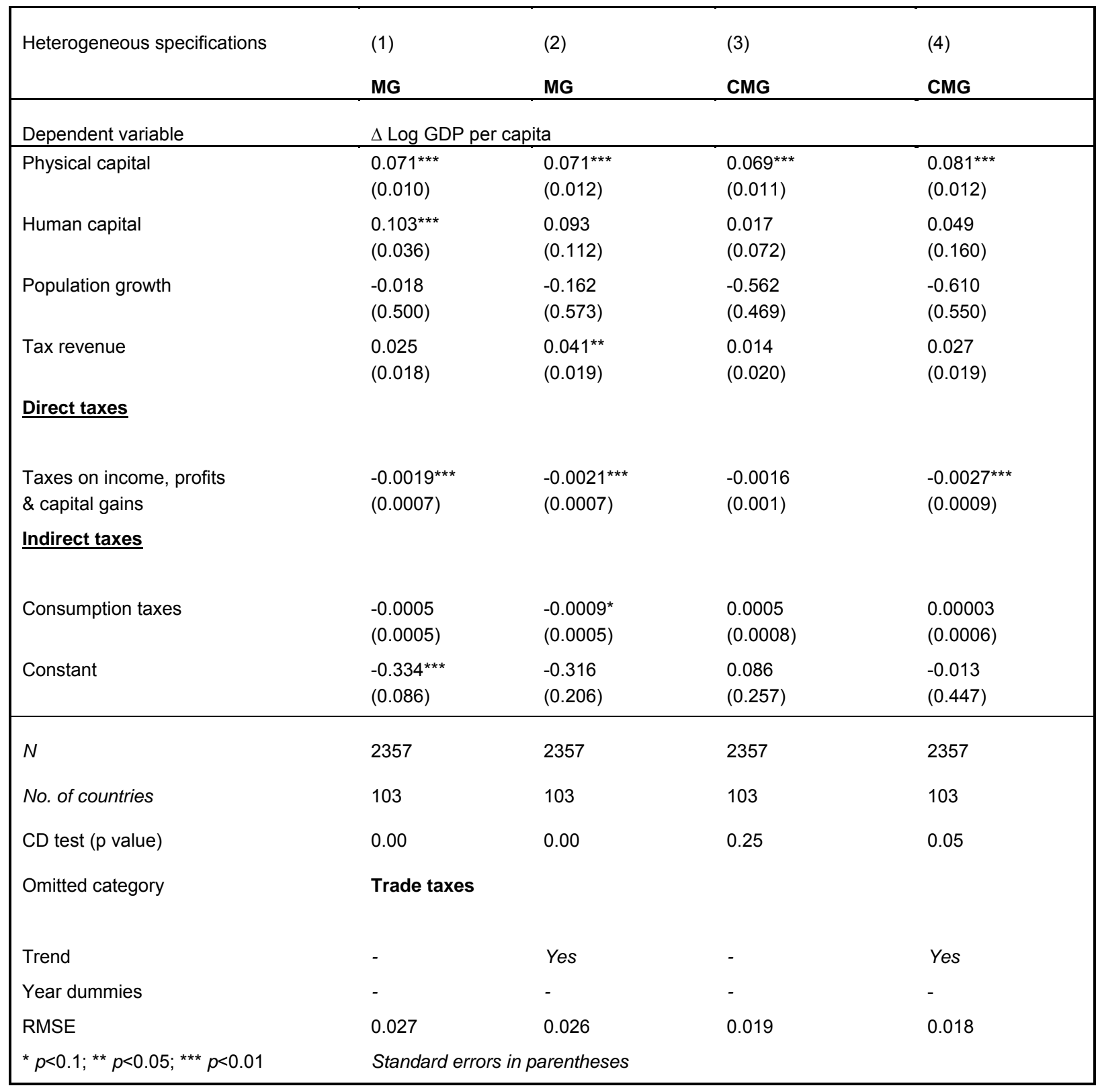

Source: ICTD GRD (2014).

In Tables $4 \mathrm{a}$ and $4 \mathrm{~b}$, we include direct and trade taxes' share of total revenue, whilst omitting consumption taxes. We again see that any revenue-neutral increase in direct taxes, this time offset by a reduction in consumption taxes, is harmful for GDP growth rates. Notably, however, results in column 4 of Table $4 \mathrm{~b}$ suggest a smaller negative coefficient than in Table $3 \mathrm{~b}$; a percentage point increase in income taxes offset by a reduction in consumption taxes leads to a 0.17 per cent decrease in the rate of GDP growth. This is significantly less than that arising from a revenue-neutral decrease in trade taxes, which is around 0.27 per cent. Thus it seems apparent that reforms away from trade taxes towards either income or consumption taxes have not led to positive impacts on GDP growth rates. Of course, the primary aim of tax reform is an increase in revenue, which may translate to growth effects in the longer term via higher levels of government expenditure; however these effects are difficult to disentangle without relevant expenditure data. 
Table 4a Full sample, pooled specifications, consumption taxes omitted

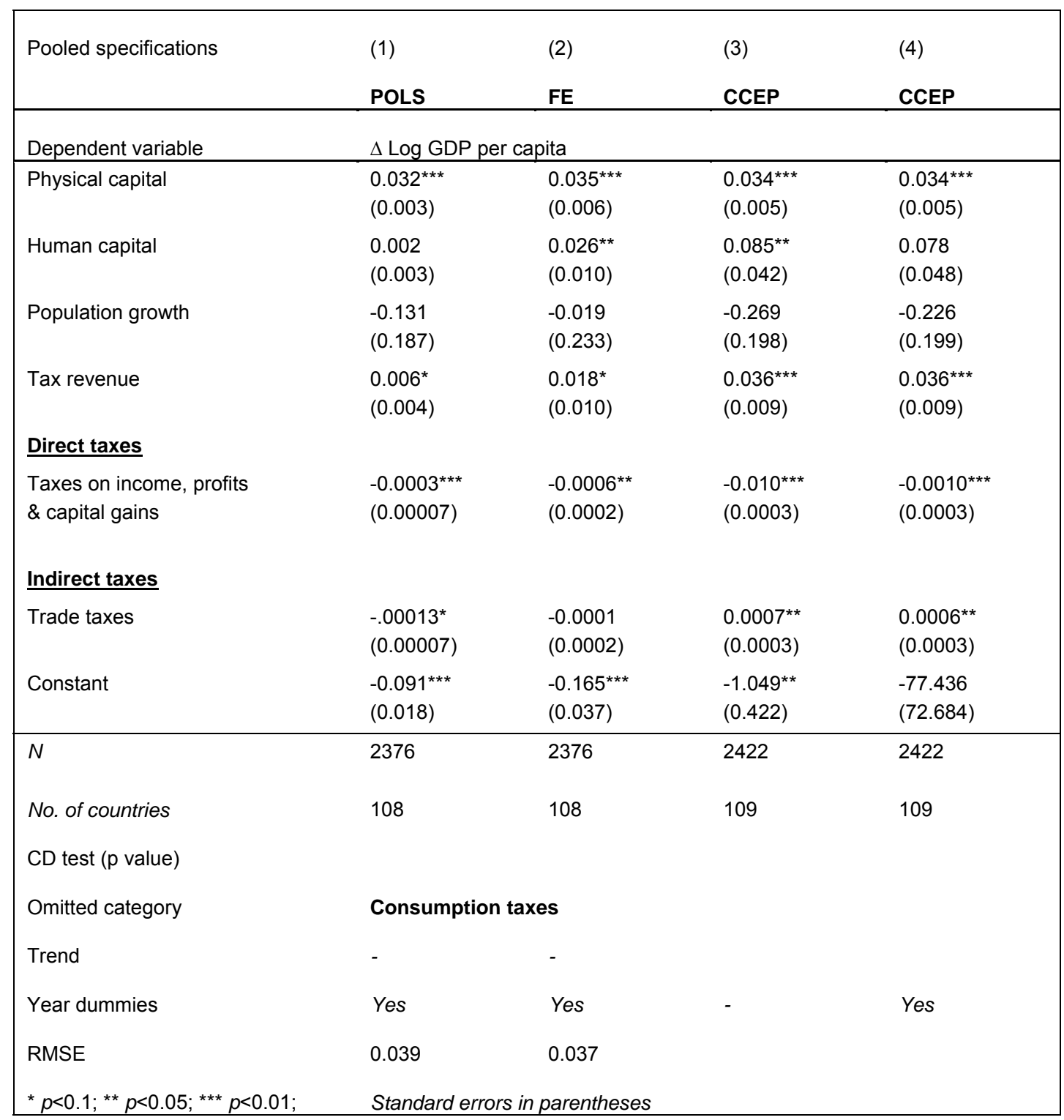

Source: ICTD GRD (2014) 
Table 4b Full sample, heterogeneous specifications, consumption taxes omitted

\begin{tabular}{|c|c|c|c|c|}
\hline Heterogeneous specifications & (1) & $(2)$ & (3) & $(4)$ \\
\hline & MG & MG & CMG & CMG \\
\hline Dependent variable & \multicolumn{4}{|c|}{$\Delta$ Log GDP per capita } \\
\hline Physical capital & $\begin{array}{l}0.071^{* * *} \\
(0.010)\end{array}$ & $\begin{array}{l}0.071^{* * *} \\
(0.012)\end{array}$ & $\begin{array}{l}0.069^{* * *} \\
(0.011)\end{array}$ & $\begin{array}{l}0.081^{\star \star *} \\
(0.012)\end{array}$ \\
\hline Human capital & $\begin{array}{l}0.102^{* * *} \\
(0.036)\end{array}$ & $\begin{array}{l}0.092 \\
(0.113)\end{array}$ & $\begin{array}{l}0.030 \\
(0.069)\end{array}$ & $\begin{array}{l}0.067 \\
(0.165)\end{array}$ \\
\hline Population growth & $\begin{array}{l}-0.173 \\
(0.500)\end{array}$ & $\begin{array}{l}-0.159 \\
(0.573)\end{array}$ & $\begin{array}{l}-0.574 \\
(0.471)\end{array}$ & $\begin{array}{l}-0.617 \\
(0.550)\end{array}$ \\
\hline Tax revenue & $\begin{array}{l}0.025 \\
(0.018)\end{array}$ & $\begin{array}{l}0.041^{* *} \\
(0.019)\end{array}$ & $\begin{array}{l}0.014 \\
(0.020)\end{array}$ & $\begin{array}{l}0.027 \\
(0.019)\end{array}$ \\
\hline \multicolumn{5}{|l|}{ Direct taxes } \\
\hline $\begin{array}{l}\text { Taxes on income, profits } \\
\& \text { capital gains }\end{array}$ & $\begin{array}{l}-0.001^{* * *} \\
(0.0004)\end{array}$ & $\begin{array}{l}-0.0012^{* *} \\
(0.0005)\end{array}$ & $\begin{array}{l}-0.0014^{* * *} \\
(0.0005)\end{array}$ & $\begin{array}{l}-0.0017^{\star * *} \\
(0.0006)\end{array}$ \\
\hline \multicolumn{5}{|l|}{ Indirect taxes } \\
\hline Trade taxes & $\begin{array}{l}0.0005 \\
(0.0005)\end{array}$ & $\begin{array}{l}0.0009^{*} \\
(0.0005)\end{array}$ & $\begin{array}{l}-0.0005 \\
(0.0008)\end{array}$ & $\begin{array}{l}-0.0003 \\
(0.0007)\end{array}$ \\
\hline Constant & $\begin{array}{l}-0.442^{* * *} \\
(0.0005)\end{array}$ & $\begin{array}{l}-0.376^{* *} \\
(0.181)\end{array}$ & $\begin{array}{l}-0.106 \\
(0.328)\end{array}$ & $\begin{array}{l}-0.309 \\
(0.383)\end{array}$ \\
\hline$N$ & 2357 & 2341 & 2357 & 2341 \\
\hline No. of countries & 103 & 101 & 103 & 101 \\
\hline$C D$ test ( $p$ value) & 0.00 & 0.00 & 0.03 & 0.16 \\
\hline Omitted category & \multicolumn{4}{|c|}{ Consumption taxes } \\
\hline Trend & - & Yes & - & Yes \\
\hline Year dummies & - & - & - & - \\
\hline RMSE & 0.027 & 0.026 & 0.019 & 0.018 \\
\hline${ }^{*} p<0.1 ;{ }^{* *} p<0.05 ;{ }^{* * *} p<0.01$ & Standard & arentheses & & \\
\hline
\end{tabular}

Source: ICTD GRD (2014).

Table 5 displays results from a set of regressions that treat personal and corporate income taxes (PIT and CIT respectively) separately. As discussed above (Section 4) this requires using a smaller sample of just under ninety countries. Results suggest that revenue-neutral shifts towards PIT (either from trade or consumption taxes) are most harmful for growth. This result is in line with that of Acosta-Ormaechea and Yoo (2012), who also find PIT are more growth-reducing than CIT. Estimates shown in columns 4 and 5 indicate that revenue-neutral shifts towards consumption taxes (offset by either PIT or CIT) have positive effects on the growth rate of GDP per capita. Indeed, the coefficient attached to PIT suggests a point increase in offset by trade or consumption taxes, holding the other categories constant, has a negative effect on GDP growth rates of around 0.4 per cent. It appears from columns 4 and 5 that revenue-neutral shifts between the two types of income tax have no effect on growth rates. ${ }^{21}$

$21 \quad$ The results reported in Tables 2-4 are robust to restricting the sample to those countries used in Table 5. We report only the CMG results in this section; results from other specifications are available from authors upon request. 
Table 5 CMG regressions, separate PIT and CIT categories

\begin{tabular}{|c|c|c|c|c|c|}
\hline CMG regressions & $(1)$ & $(2)$ & (3) & (4) & $(5)$ \\
\hline Dependent variable & \multicolumn{5}{|c|}{$\Delta$ Log GDP per capita } \\
\hline Physical capital & $\begin{array}{l}0.106^{\star \star \star} \\
(0.016)\end{array}$ & $\begin{array}{l}0.106^{\star \star \star} \\
(0.016)\end{array}$ & $\begin{array}{l}0.098^{* \star \star} \\
(0.012)\end{array}$ & $\begin{array}{l}0.106^{\star * *} \\
(0.016)\end{array}$ & $\begin{array}{l}0.106^{\star * *} \\
(0.016)\end{array}$ \\
\hline Human capital & $\begin{array}{l}-0.100 \\
(0.103)\end{array}$ & $\begin{array}{l}-0.100 \\
(0.103)\end{array}$ & $\begin{array}{l}-0.062 \\
(0.086)\end{array}$ & $\begin{array}{l}-0.100 \\
(0.103)\end{array}$ & $\begin{array}{l}-0.100 \\
(0.103)\end{array}$ \\
\hline Population growth & $\begin{array}{l}-0.290 \\
(0.428)\end{array}$ & $\begin{array}{l}-0.290 \\
(0.428)\end{array}$ & $\begin{array}{l}-0.175 \\
(0.429)\end{array}$ & $\begin{array}{l}-0.290 \\
(0.428)\end{array}$ & $\begin{array}{l}-0.290 \\
(0.428)\end{array}$ \\
\hline Tax revenue & $\begin{array}{l}0.009 \\
(0.027)\end{array}$ & $\begin{array}{l}0.009 \\
(0.027)\end{array}$ & $\begin{array}{l}-0.004 \\
(0.030)\end{array}$ & $\begin{array}{l}0.009 \\
(0.027)\end{array}$ & $\begin{array}{l}0.009 \\
(0.027)\end{array}$ \\
\hline \multicolumn{6}{|l|}{ Direct taxes } \\
\hline PIT & $\begin{array}{l}-0.0045^{* *} \\
(0.002)\end{array}$ & $\begin{array}{l}-0.004^{* * *} \\
(0.001)\end{array}$ & & & $\begin{array}{l}-0.001 \\
(0.001)\end{array}$ \\
\hline CIT & $\begin{array}{l}0.001 \\
(0.002)\end{array}$ & $\begin{array}{l}-0.002^{* *} \\
(0.001)\end{array}$ & & $\begin{array}{l}0.001 \\
(0.001)\end{array}$ & \\
\hline \multicolumn{6}{|l|}{ Indirect taxes } \\
\hline Trade taxes & & $\begin{array}{l}-0.0003 \\
(0.002)\end{array}$ & $\begin{array}{l}0.001 \\
(0.001)\end{array}$ & $\begin{array}{l}0.004^{* *} \\
(0.002)\end{array}$ & $\begin{array}{l}-0.001 \\
(0.002)\end{array}$ \\
\hline Consumption taxes & $\begin{array}{l}0.001 \\
(0.002)\end{array}$ & & $\begin{array}{l}0.001^{* *} \\
(0.0005)\end{array}$ & $\begin{array}{l}0.004^{* * *} \\
(0.001)\end{array}$ & $\begin{array}{l}0.002^{* *} \\
(0.001)\end{array}$ \\
\hline Constant & $\begin{array}{l}-0.091 \\
(0.458)\end{array}$ & $\begin{array}{l}0.230 \\
(0.351)\end{array}$ & $\begin{array}{l}0.286 \\
(0.439)\end{array}$ & $\begin{array}{l}0.116 \\
(0.502)\end{array}$ & $\begin{array}{l}0.777 \\
(0.609)\end{array}$ \\
\hline$N$ & 1787 & 1747 & 1787 & 1747 & 1747 \\
\hline \# of groups & 88 & 83 & 88 & 83 & 83 \\
\hline RMSE & 0.015 & 0.013 & 0.015 & 0.013 & 0.013 \\
\hline Omitted category & Trade & Consumption & Direct & PIT & CIT \\
\hline${ }^{*} p<0.1 ;{ }^{* *} p<0.05 ;{ }^{* * *} p<0.01$ & \multicolumn{5}{|c|}{ Standard errors in parentheses } \\
\hline
\end{tabular}

Source ICTD GRD (2014).

\subsection{Results by country grouping}

Table 6 presents results from a set of MG estimations where the sample has been subdivided into low-, middle- and high-income, along with a separate category for OECD countries. ${ }^{22}$

22 We present results from MG estimations due to data limitations - when we attempted to run the same specifications using the CMG estimator, we were unable to obtain results for low-income countries, likely due to the smaller sample and more unbalanced data. (NB. This applies not only to the disaggregated tax data but also the other covariates included; missing observations for any one of the variables included leads to that country being dropped from the estimation.) Indeed for certain specifications we were also unable to obtain results for the middle-income countries. Our choice was between presenting results using our preferred estimator, or to present results from the full set of income categories. The latter was chosen, as the aim of the current section is to highlight differences across income groups. 
Table 6 MG regressions by income group

\begin{tabular}{|c|c|c|c|c|c|c|c|c|}
\hline MG regressions & $(1)$ & (2) & (3) & (4) & (5) & (6) & (7) & (8) \\
\hline Income group & Low & Middle & High & OECD & Low & Middle & High & OECD \\
\hline Dependent variable & \multicolumn{8}{|c|}{$\Delta$ Log GDP per capita } \\
\hline Physical capital & $\begin{array}{l}0.030 \\
(0.022)\end{array}$ & $\begin{array}{l}0.070^{* * *} \\
(0.017)\end{array}$ & $\begin{array}{l}0.128^{\star * \star} \\
(0.015)\end{array}$ & $\begin{array}{l}0.134^{* * *} \\
(0.017)\end{array}$ & $\begin{array}{l}0.030 \\
(0.022)\end{array}$ & $\begin{array}{l}0.070^{* * \star} \\
(0.017)\end{array}$ & $\begin{array}{l}0.128^{* * *} \\
(0.015)\end{array}$ & $\begin{array}{l}0.134^{\star * \star} \\
(0.017)\end{array}$ \\
\hline Human capital & $\begin{array}{l}0.227^{* * *} \\
(0.070)\end{array}$ & $\begin{array}{l}0.178 \\
(0.172)\end{array}$ & $\begin{array}{l}0.065 \\
(0.066)\end{array}$ & $\begin{array}{l}0.048 \\
(0.076)\end{array}$ & $\begin{array}{l}0.227^{* * *} \\
(0.070)\end{array}$ & $\begin{array}{l}0.178 \\
(0.172)\end{array}$ & $\begin{array}{l}0.065 \\
(0.065)\end{array}$ & $\begin{array}{l}0.048 \\
(0.076)\end{array}$ \\
\hline Population growth & $\begin{array}{l}0.411 \\
(1.445)\end{array}$ & $\begin{array}{l}0.06 \\
(2.03)\end{array}$ & $\begin{array}{l}-2.385^{\star * *} \\
(0.860)\end{array}$ & $\begin{array}{l}-2.340^{* * *} \\
(0.830)\end{array}$ & $\begin{array}{l}0.411 \\
(1.445)\end{array}$ & $\begin{array}{l}0.06 \\
(2.03)\end{array}$ & $\begin{array}{l}-2.385^{\star * \star} \\
(0.860)\end{array}$ & $\begin{array}{l}-2.340^{* * *} \\
(0.830)\end{array}$ \\
\hline & $\begin{array}{l}-0.015 \\
(0.049)\end{array}$ & $\begin{array}{l}0.035 \\
(0.037)\end{array}$ & $\begin{array}{l}0.025 \\
(0.036)\end{array}$ & $\begin{array}{l}0.043 \\
(0.040)\end{array}$ & $\begin{array}{l}-0.015 \\
(0.049)\end{array}$ & $\begin{array}{l}0.035 \\
(0.037)\end{array}$ & $\begin{array}{l}0.025 \\
(0.036)\end{array}$ & $\begin{array}{l}0.043 \\
(0.040)\end{array}$ \\
\hline \multicolumn{9}{|c|}{$\begin{array}{l}\text { Taxes on income, profits } \\
\& \text { capital gains }\end{array}$} \\
\hline PIT & $\begin{array}{l}-0.005^{\star *} \\
(0.002)\end{array}$ & $\begin{array}{l}-0.005^{* * *} \\
(0.002)\end{array}$ & $\begin{array}{l}-0.001 \\
(0.003)\end{array}$ & $\begin{array}{l}-0.001 \\
(0.004)\end{array}$ & $\begin{array}{l}-0.003 \\
(0.003)\end{array}$ & $\begin{array}{l}-0.006^{\star * *} \\
(0.002)\end{array}$ & $\begin{array}{l}-0.002^{*} \\
(0.001)\end{array}$ & $\begin{array}{l}-0.0027^{* *} \\
(0.001)\end{array}$ \\
\hline & $\begin{array}{l}0.002 \\
(0.002)\end{array}$ & $\begin{array}{l}-0.002^{*} \\
(0.001)\end{array}$ & $\begin{array}{l}0.0005 \\
(0.003)\end{array}$ & $\begin{array}{l}0.002 \\
(0.004)\end{array}$ & $\begin{array}{l}0.0037^{*} \\
(0.0019)\end{array}$ & $\begin{array}{l}-0.002 \\
(0.001)\end{array}$ & $\begin{array}{l}0.0002 \\
(0.001)\end{array}$ & $\begin{array}{l}0.0007 \\
(0.001)\end{array}$ \\
\hline \multicolumn{9}{|l|}{ Indirect taxes } \\
\hline Trade taxes & & & & & $\begin{array}{l}-0.000 \\
(0.001)\end{array}$ & $\begin{array}{l}0.001 \\
(0.001)\end{array}$ & $\begin{array}{l}-0.001 \\
(0.002)\end{array}$ & $\begin{array}{l}-0.002 \\
(0.003)\end{array}$ \\
\hline Consumption taxes & $\begin{array}{l}0.000 \\
(0.001)\end{array}$ & $\begin{array}{l}-0.001 \\
(0.001)\end{array}$ & $\begin{array}{l}0.001 \\
(0.002)\end{array}$ & $\begin{array}{l}0.002 \\
(0.004)\end{array}$ & & & & \\
\hline Constant & $\begin{array}{l}-0.217 \\
(0.247)\end{array}$ & $\begin{array}{l}-0.433 \\
(0.553)\end{array}$ & $\begin{array}{l}-0.442^{*} \\
(0.249)\end{array}$ & $\begin{array}{l}-0.479 \\
(0.343)\end{array}$ & $\begin{array}{l}-0.315 \\
(0.207)\end{array}$ & $\begin{array}{l}-0.514 \\
(0.601)\end{array}$ & $\begin{array}{l}-0.552^{* * *} \\
(0.194)\end{array}$ & $\begin{array}{l}-0.631^{* * *} \\
(0.223)\end{array}$ \\
\hline$N$ & 356 & 519 & 872 & 750 & 356 & 519 & 872 & 750 \\
\hline $\begin{array}{l}\text { No. of countries } \\
\text { CD test ( } p \text { value) }\end{array}$ & 23 & 26 & 34 & 28 & 23 & 26 & 34 & 28 \\
\hline Omitted category & Trade ta & & & & Consum & n taxes & & \\
\hline RMSE & 0.029 & 0.024 & 0.018 & 0.016 & 0.03 & 0.024 & 0.018 & 0.016 \\
\hline
\end{tabular}

Source: ICTD GRD (2014) 
Results from columns 1-4 indicate that revenue-neutral shifts away from trade taxes towards PIT have had a negative and significant impact on growth rates in low- and middle-income, but not in high-income, countries. This result is not surprising considering the relatively low share of trade taxes in high-income countries' tax mix, and also the relative stability of their tax mix over the sample period. Results in columns 5-8 suggest that shifts away from consumption taxes towards income taxes are also harmful for growth; again it appears that this effect is primarily felt through revenue-neutral increases in PIT, rather than CIT. Specifically, the effect is felt most strongly in middle-income countries, although the coefficient on PIT in OECD countries is also negative and significant. This is similar to the findings of Acosta-Ormaechea and Yoo (2012), who find the greatest growth-reducing effect comes from PIT and social security contributions. Given that, at this stage, we have been unable to obtain estimates for this set of regressions using the CMG estimator, we advise caution in the reading of these results. The only other study to have attempted a similar analysis of countries by income group, Acosta-Ormaechea and Yoo (2012), also met issues with data for low-income economies. These authors found little association between the tax policy variables and GDP growth rates; given the difficulties encountered here, we empathise with the complications faced when working with low-income countries.

\subsection{Excluding resource-rich countries}

In developing countries, growth is frequently driven by natural resource wealth. As a further robustness check on the aforementioned results, we treat countries where non-tax revenue exceeds 10 per cent of GDP as 'resource rich' and exclude them. ${ }^{23}$ Table 7 replicates selected CMG estimations from above as indicated. It is clear in almost all cases that the previous results remain robust. We do however see when replicating column 1 from Table 5 that the previously reported result (revenue-neutral shifts from trade towards PIT was growthreducing) is no longer statistically significant.

This exercise is repeated for the specifications where countries are divided according to income category; results are displayed in Table 8 . We only display middle- and high-income countries, as the low-income and OECD categories remained unchanged following the exclusion of resource-rich countries. Again, the previous results are robust to the exclusion of these countries; the result that revenue-neutral increases in PIT, offset by reductions in consumption taxes, are harmful for growth in high-income countries is now significant at the 5 per cent level. The coefficient estimates on PIT are larger for middle-income countries; again we urge caution when drawing conclusions, as these are results from the MG estimator, and as such do not account for cross-sectional dependencies.

The countries excluded as a result are: Bahrain, Bolivia, Botswana, Cameroon, Republic of the Congo, Equatorial

Guinea, Gabon, Indonesia, Iran, Kuwait, Malaysia, Morocco, Trinidad and Tobago, and Venezuela. 
Table 7 CMG regressions excluding resource-rich countries

\begin{tabular}{|c|c|c|c|c|c|c|c|c|c|c|}
\hline \multirow{2}{*}{$\begin{array}{l}\text { (Table and column } \\
\text { replicated) } \\
\text { Dependent variable } \\
\end{array}$} & \multicolumn{2}{|l|}{$(2 b$, Col.3) } & \multicolumn{2}{|l|}{ (3b, Col.3) } & \multicolumn{2}{|l|}{ (4b, Col.3) } & \multicolumn{2}{|l|}{ (5, Col.1) } & \multicolumn{2}{|l|}{$(5$, Col.2) } \\
\hline & \multicolumn{10}{|c|}{$\Delta$ Log GDP per capita } \\
\hline Physical capital & $\begin{array}{l}0.061^{* \star *} \\
(0.010)\end{array}$ & $\begin{array}{l}0.065^{\star \star \star} \\
(0.011)\end{array}$ & $\begin{array}{l}0.069^{* * *} \\
(0.011)\end{array}$ & $\begin{array}{l}0.074^{\star \star *} \\
(0.012)\end{array}$ & $\begin{array}{l}0.069^{* * *} \\
(0.011)\end{array}$ & $\begin{array}{l}0.073^{* * *} \\
(0.012)\end{array}$ & $\begin{array}{l}0.106^{\star \star \star} \\
(0.016)\end{array}$ & $\begin{array}{l}0.114^{* * *} \\
(0.018)\end{array}$ & $\begin{array}{l}0.106^{\star * *} \\
(0.016)\end{array}$ & $\begin{array}{l}0.114^{\star \star *} \\
(0.018)\end{array}$ \\
\hline Human capital & $\begin{array}{l}0.042 \\
(0.069)\end{array}$ & $\begin{array}{l}0.046 \\
(0.067)\end{array}$ & $\begin{array}{l}0.017 \\
(0.072)\end{array}$ & $\begin{array}{l}0.069 \\
(0.079)\end{array}$ & $\begin{array}{l}0.030 \\
(0.069)\end{array}$ & $\begin{array}{l}0.068 \\
(0.079)\end{array}$ & $\begin{array}{l}-0.100 \\
(0.103)\end{array}$ & $\begin{array}{l}-0.101 \\
(0.103)\end{array}$ & $\begin{array}{l}-0.100 \\
(0.103)\end{array}$ & $\begin{array}{l}-0.101 \\
(0.103)\end{array}$ \\
\hline Population growth & $\begin{array}{l}-0.596 \\
(0.483)\end{array}$ & $\begin{array}{l}-0.517 \\
(0.499)\end{array}$ & $\begin{array}{l}-0.562 \\
(0.469)\end{array}$ & $\begin{array}{l}-0.432 \\
(0.663)\end{array}$ & $\begin{array}{l}-0.574 \\
(0.471)\end{array}$ & $\begin{array}{l}-0.381 \\
(0.675)\end{array}$ & $\begin{array}{l}-0.290 \\
(0.428)\end{array}$ & $\begin{array}{l}-1.075^{\star *} \\
(0.546)\end{array}$ & $\begin{array}{l}-0.290 \\
(0.428)\end{array}$ & $\begin{array}{l}-1.075^{\star \star} \\
(0.546)\end{array}$ \\
\hline Tax revenue & $\begin{array}{l}0.024 \\
(0.019)^{*}\end{array}$ & $\begin{array}{l}0.023 \\
(0.018)\end{array}$ & $\begin{array}{l}0.014 \\
(0.020)\end{array}$ & $\begin{array}{l}0.019 \\
(0.019)\end{array}$ & $\begin{array}{l}0.014 \\
(0.020)\end{array}$ & $\begin{array}{l}0.018 \\
(0.019)\end{array}$ & $\begin{array}{l}0.009 \\
(0.027)\end{array}$ & $\begin{array}{l}-0.008 \\
(0.036)\end{array}$ & $\begin{array}{l}0.009 \\
(0.027)\end{array}$ & $\begin{array}{l}-0.008 \\
(0.036)\end{array}$ \\
\hline \multicolumn{11}{|l|}{ Direct taxes } \\
\hline $\begin{array}{l}\text { Taxes on income, profits } \\
\& \text { capital gains }\end{array}$ & $\begin{array}{l}-0.0016^{* \star *} \\
(0.0005)\end{array}$ & $\begin{array}{l}-0.0013^{\star * *} \\
(0.001)\end{array}$ & $\begin{array}{l}-0.0016 \\
(0.001)\end{array}$ & $\begin{array}{l}-0.0022^{* *} \\
(0.001)\end{array}$ & $\begin{array}{l}-0.0014^{* * *} \\
(0.0005)\end{array}$ & $\begin{array}{l}-0.0011^{*} \\
(0.001)\end{array}$ & & & & \\
\hline PIT & & & & & & & $\begin{array}{l}-0.0045^{\star *} \\
(0.002)\end{array}$ & $\begin{array}{l}-0.0035 \\
(0.0024)\end{array}$ & $\begin{array}{l}-0.004^{* * *} \\
(0.001)\end{array}$ & $\begin{array}{l}-0.004^{* * *} \\
(0.001)\end{array}$ \\
\hline CIT & & & & & & & $\begin{array}{l}0.001 \\
(0.002)\end{array}$ & $\begin{array}{l}0.0013 \\
(0.002)\end{array}$ & $\begin{array}{l}-0.002^{\star *} \\
(0.001)\end{array}$ & $\begin{array}{l}-0.0007 \\
(0.0013)\end{array}$ \\
\hline \multicolumn{11}{|l|}{ Indirect taxes } \\
\hline Trade taxes & & & & & $\begin{array}{l}-0.0005 \\
(0.0008)\end{array}$ & $\begin{array}{l}0.0005 \\
(0.0008)\end{array}$ & & & $\begin{array}{l}-0.0003 \\
(0.002)\end{array}$ & $\begin{array}{l}-0.0019 \\
(0.0017)\end{array}$ \\
\hline Consumption taxes & & & $\begin{array}{l}0.0005 \\
(0.0008)\end{array}$ & $\begin{array}{l}-0.001 \\
(0.001)\end{array}$ & & & $\begin{array}{l}0.001 \\
(0.002)\end{array}$ & $\begin{array}{l}0.0021 \\
(0.0018)\end{array}$ & & \\
\hline Constant & $\begin{array}{l}-0.325^{*} \\
(0.196)\end{array}$ & $\begin{array}{l}-0.622^{* \star *} \\
(0.211)\end{array}$ & $\begin{array}{l}0.086 \\
(0.257)\end{array}$ & $\begin{array}{l}-0.344 \\
(0.280)\end{array}$ & $\begin{array}{l}-0.106 \\
(0.328)\end{array}$ & $\begin{array}{l}-0.736^{\star *} \\
(0.375)\end{array}$ & $\begin{array}{l}-0.091 \\
(0.458)\end{array}$ & $\begin{array}{l}0.046 \\
(0.568)\end{array}$ & $\begin{array}{l}0.230 \\
(0.351)\end{array}$ & $\begin{array}{l}-0.008 \\
(0.357)\end{array}$ \\
\hline $\begin{array}{l}N \\
\text { No. of countries }\end{array}$ & $\begin{array}{l}2357 \\
103\end{array}$ & $\begin{array}{l}2052 \\
91\end{array}$ & $\begin{array}{l}2357 \\
103\end{array}$ & $\begin{array}{l}2052 \\
91\end{array}$ & $\begin{array}{l}2357 \\
103\end{array}$ & $\begin{array}{l}1594 \\
75\end{array}$ & $\begin{array}{l}1787 \\
88\end{array}$ & $\begin{array}{l}1594 \\
75\end{array}$ & $\begin{array}{l}1747 \\
83\end{array}$ & $\begin{array}{l}1594 \\
75\end{array}$ \\
\hline Omitted category & Indirect & & Trade & & Consumpt & & Indirect & & Consump & \\
\hline $\begin{array}{l}\text { Resource-rich countries } \\
\text { RMSE }\end{array}$ & $\begin{array}{l}\text { Included } \\
0.020\end{array}$ & $\begin{array}{l}\text { Excluded } \\
0.020\end{array}$ & $\begin{array}{l}\text { Included } \\
0.019\end{array}$ & $\begin{array}{l}\text { Excluded } \\
0.018\end{array}$ & $\begin{array}{l}\text { Included } \\
0.019\end{array}$ & $\begin{array}{l}\text { Excluded } \\
0.018\end{array}$ & $\begin{array}{l}\text { Included } \\
0.013\end{array}$ & $\begin{array}{l}\text { Excluded } \\
0.011\end{array}$ & \begin{tabular}{|l} 
Included \\
0.013 \\
\end{tabular} & $\begin{array}{l}\text { Excluded } \\
0.011\end{array}$ \\
\hline
\end{tabular}

Source: ICTD GRD (2014) 
Table 8 MG regressions by income group, excluding resource-rich countries

\begin{tabular}{|c|c|c|c|c|c|c|c|c|}
\hline $\begin{array}{l}\text { Table and column } \\
\text { replicated }\end{array}$ & \multicolumn{2}{|l|}{$(6$, Col.2) } & \multicolumn{2}{|l|}{ (6, Col.3) } & \multicolumn{2}{|l|}{ (6, Col.6) } & \multicolumn{2}{|l|}{ (6, Col.7) } \\
\hline Income group & \multicolumn{2}{|l|}{ Middle } & \multicolumn{2}{|l|}{ High } & \multicolumn{2}{|l|}{ Middle } & \multicolumn{2}{|l|}{ High } \\
\hline Dependent variable & \multicolumn{8}{|c|}{$\Delta$ Log GDP per capita } \\
\hline Physical capital & $\begin{array}{l}0.070^{\star \star *} \\
(0.017)\end{array}$ & $\begin{array}{l}0.076^{\star \star *} \\
(0.019)\end{array}$ & $\begin{array}{l}0.128^{\star * *} \\
(0.015)\end{array}$ & $\begin{array}{l}0.123^{\star * *} \\
(0.015)\end{array}$ & $\begin{array}{l}0.070^{\star \star \star} \\
(0.017)\end{array}$ & $\begin{array}{l}0.076^{\star * *} \\
(0.019)\end{array}$ & $\begin{array}{l}0.128^{\star * \star} \\
(0.015)\end{array}$ & $\begin{array}{l}0.123^{\star * *} \\
(0.015)\end{array}$ \\
\hline Human capital & $\begin{array}{l}0.178 \\
(0.172)\end{array}$ & $\begin{array}{l}-0.041 \\
(0.368)\end{array}$ & $\begin{array}{l}0.065 \\
(0.066)\end{array}$ & $\begin{array}{l}0.053 \\
(0.069)\end{array}$ & $\begin{array}{l}0.178 \\
(0.172)\end{array}$ & $\begin{array}{l}-0.041 \\
(0.368)\end{array}$ & $\begin{array}{l}0.065 \\
(0.065)\end{array}$ & $\begin{array}{l}0.053 \\
(0.068)\end{array}$ \\
\hline Population growth & $\begin{array}{l}0.06 \\
(2.03)\end{array}$ & $\begin{array}{l}0.201 \\
(2.117)\end{array}$ & $\begin{array}{l}-2.385^{* * *} \\
(0.860)\end{array}$ & $\begin{array}{l}-2.382 \\
(0.680)^{\star \star \star}\end{array}$ & $\begin{array}{l}0.06 \\
(2.03)\end{array}$ & $\begin{array}{l}0.201 \\
(2.117)\end{array}$ & $\begin{array}{l}-2.385^{\star * *} \\
(0.860)\end{array}$ & $\begin{array}{l}-2.382^{* * *} \\
(0.680)\end{array}$ \\
\hline Tax revenue & $\begin{array}{l}0.035 \\
(0.037)\end{array}$ & $\begin{array}{l}0.034 \\
(0.039)\end{array}$ & $\begin{array}{l}0.025 \\
(0.036)\end{array}$ & $\begin{array}{l}0.031 \\
(0 . .038)\end{array}$ & $\begin{array}{l}0.035 \\
(0.037)\end{array}$ & $\begin{array}{l}0.034 \\
(0.039)\end{array}$ & $\begin{array}{l}0.025 \\
(0.036)\end{array}$ & $\begin{array}{l}0.031 \\
(0.038)\end{array}$ \\
\hline \multicolumn{9}{|l|}{ Direct taxes } \\
\hline PIT & $\begin{array}{l}-0.005^{\star * *} \\
(0.002)\end{array}$ & $\begin{array}{l}-0.0064^{* *} \\
(0.003)\end{array}$ & $\begin{array}{l}-0.001 \\
(0.003)\end{array}$ & $\begin{array}{l}-0.0006 \\
(0.003)\end{array}$ & $\begin{array}{l}-0.006^{* * *} \\
(0.002)\end{array}$ & $\begin{array}{l}-0.0085^{\star * *} \\
(0.002)\end{array}$ & $\begin{array}{l}-0.002^{*} \\
(0.001)\end{array}$ & $\begin{array}{l}-0.0025^{\text {** }} \\
(0.0012)\end{array}$ \\
\hline $\mathrm{CIT}$ & $\begin{array}{l}-0.002^{*} \\
(0.001)\end{array}$ & $\begin{array}{l}-0.0016 \\
(0.001)\end{array}$ & $\begin{array}{l}0.0005 \\
(0.003)\end{array}$ & $\begin{array}{l}0.0019 \\
(0.003)\end{array}$ & $\begin{array}{l}-0.002 \\
(0.001)\end{array}$ & $\begin{array}{l}-0.0019 \\
(0.001)\end{array}$ & $\begin{array}{l}0.0002 \\
(0.001)\end{array}$ & $\begin{array}{l}0.0003 \\
(0.0007)\end{array}$ \\
\hline \multicolumn{9}{|l|}{ Indirect taxes } \\
\hline Trade taxes & & & & & $\begin{array}{l}0.001 \\
(0.001)\end{array}$ & $\begin{array}{l}0.0004 \\
(0.0008)\end{array}$ & $\begin{array}{l}-0.001 \\
(0.002)\end{array}$ & $\begin{array}{l}-0.002 \\
(0.002)\end{array}$ \\
\hline Consumption taxes & $\begin{array}{l}-0.001 \\
(0.001)\end{array}$ & $\begin{array}{l}-0.0001 \\
(0.001)\end{array}$ & $\begin{array}{l}0.001 \\
(0.002)\end{array}$ & $\begin{array}{l}0.0017 \\
(0.002)\end{array}$ & & & & \\
\hline Constant & $\begin{array}{l}-0.433 \\
(0.553)\end{array}$ & $\begin{array}{l}-0.068 \\
(0.889) \\
\end{array}$ & $\begin{array}{l}-0.442^{*} \\
(0.249) \\
\end{array}$ & $\begin{array}{l}-0.386 \\
(0.264)\end{array}$ & $\begin{array}{l}-0.514 \\
(0.601)\end{array}$ & $\begin{array}{l}-0.187 \\
(0.871) \\
\end{array}$ & $\begin{array}{l}-0.552^{* * *} \\
(0.194) \\
\end{array}$ & $\begin{array}{l}-0.545^{\star * *} \\
(0.198) \\
\end{array}$ \\
\hline $\begin{array}{l}N \\
\text { No. of countries }\end{array}$ & $\begin{array}{l}519 \\
26 \\
\end{array}$ & $\begin{array}{l}401 \\
20 \\
\end{array}$ & $\begin{array}{l}872 \\
34 \\
\end{array}$ & $\begin{array}{l}837 \\
32 \\
\end{array}$ & $\begin{array}{l}519 \\
26 \\
\end{array}$ & $\begin{array}{l}401 \\
20 \\
\end{array}$ & $\begin{array}{l}872 \\
34 \\
\end{array}$ & $\begin{array}{l}837 \\
32 \\
\end{array}$ \\
\hline Omitted category & Trade tax & & Trade tas & & Consump & xes & Consump & xes \\
\hline RMSE & 0.030 & 0.022 & 0.016 & 0.016 & 0.030 & 0.022 & 0.016 & 0.016 \\
\hline
\end{tabular}

Source: GRD (ICTD, 2014) 


\section{Limitations and possibilities for further} research

We acknowledge that a study of this nature brings with it a number of limitations. Firstly, it is inherently difficult to account for the fact that tax policy changes are often announced some time in advance of their implementation. Individuals and firms may therefore adjust their behaviour (which in turn influences GDP) before the tax rate itself has actually changed. Furthermore, it is quite possible that there might be endogeneity in the sense that different taxes' share of total revenue may change due to increased levels of economic activity in different sectors as a result of some reason other than a change in the tax rate. For example, the share of taxes collected from trade may increase relative to other categories simply as a result of an increase in the volume of trade. We attempt to account for this by running a robustness check on the results in Tables $3 a$ and $3 b$, including a measure of openness to trade. ${ }^{24}$ Results, not shown but available upon request, are robust to the inclusion of this variable. This is, however, only a first attempt to tackle the endogeneity problem. Future solutions might involve averaging the data over 5-year periods in order to account for effects of the business cycle and following an Instrumental Variable (IV) estimation method. There is however a trade-off involved: by employing an alternative estimator to tackle endogeneity, we potentially lose the ability to control for CSD; both issues can bias results.

A further challenge is to account for (changes in) the efficiency of the collection of taxes, which has clear implications for GDP growth: even a well-designed tax system might be undermined by poor administration. However the human capital variable might go some way to capturing citizens' ability to understand and comply with tax laws, and the inclusion of the tax level (as a share of GDP), to an extent, serves as a control for the ability of the government to administer the tax system. ${ }^{25}$

We are also constrained, frustratingly so, by the scarcity of data for some of the covariates necessary in the empirical analysis. The GRD presents an excellent opportunity to examine the impacts of tax revenue on GDP growth for a very large sample of countries (around 200 states), yet after including the necessary control variables our sample drops to at most 109 countries.

In terms of further research in the area, it would certainly be interesting to take a closer look at the results by country grouping: this work (along with the results in Acosta-Ormaechea and Yoo 2012) has suggested that different taxes affect different countries to different extents. Whilst MG estimation allows for full parameter (country) heterogeneity, and as such can be viewed as one of the most flexible approaches to panel data, the coefficient reported is a mean. Therefore we can only capture the average effect. Furthermore, the approach of ex ante classifying countries into groups based on, for example, income per head or some other economic variable is certainly not without its limitations. It might be appropriate in future work to employ alternative selection techniques that use the information contained within the dataset in order to sort countries. ${ }^{26}$

\footnotetext{
24 Following Arnold et al. (2011), we obtain the residuals from a regression of the volume of imports and exports on log population. This represents the part of trade that is not due to country size.

25 That is, assuming that larger governments (proxied by larger tax/GDP figures) are more able to collect taxes. Of course this says nothing about the efficiency of tax collection, but it is plausible that where more people are employed in the public sector, tax collection may be more sophisticated.

26 See, for example, Bos et al. (2010), for an example of a 'latent class model' approach to growth regressions.
} 


\section{Conclusions}

The main finding of this study, that revenue-neutral shifts towards income taxes are harmful for growth, is in line with the theory discussed in Section 1 and with much of the previous empirical work reviewed in Section 2. The magnitude of the effect is however worth examining: column 4 of Table $2 \mathrm{~b}$ suggests that a percentage point increase in direct taxes, offset by a similar reduction in indirect taxes, leads to a fall in GDP growth rates of around -0.13 per cent. The results of a similar regression in Acosta-Ormaechea and Yoo (2012), the paper closest to ours in spirit, suggest a smaller effect of around -0.07 per cent. ${ }^{27}$ Thus the effect is almost double in our sample. These authors, however, use the pooled mean group procedure, which constrains long-run coefficients to be equal. ${ }^{28}$ Our results are also comparable to those of Kneller et al. (1999), who find the effects of a revenue-neutral percentage point increase in direct taxation to have a negative effect of between 0.1 and 0.2 per cent. Thus the exact magnitude of the effects uncovered is possibly driven by the choice of methodology and assumptions made concerning the data. In Table 5, we disaggregated direct tax revenue into PIT and CIT, finding that most of the negative growth effects are actually from revenue-neutral shifts towards the former. Again, this finding is similar to that uncovered by Acosta-Ormaechea and Yoo (2012), although once again the coefficient estimate reported here is larger.

The results in Table 4 are, as mentioned, potentially the most significant in a policy context, as a shift away from trade taxes has been the IMF's policy prescription for developing countries for some time now. This is, to the best of our knowledge, the first analysis that is able to explicitly consider revenue-neutral shifts away from trade taxes towards consumption or income taxes, which certainly validates efforts to improve the quality of such studies by drawing on higher-quality data. Acosta-Ormaechea and Yoo (2012) bundle trade taxes into a broader category of 'consumption and property taxes', and do not take the chance to examine the consequence of a shift away from trade taxes towards other categories. Whilst we find no robust evidence that a shift towards consumption taxes has been harmful for growth, it is certainly not clear that it has been good for growth either. There is plenty of evidence to suggest, however, that shifts towards (specifically personal) income taxes have been harmful for growth. Given that the negative coefficient attached to income taxes is larger when considering the shift away from trade taxes than consumption taxes (see Tables 3 and 4), we can tentatively conclude that such shifts have been the most harmful for economic growth rates.

These results are intriguing, especially in light of the work of Baunsgaard and Keen (2010), whose findings highlighted that revenue recovery following trade liberalisation in middle- and low-income countries had also been poor. The present findings suggesting that revenueneutral shifts away from trade taxes have had a non-positive effect on GDP growth rates, and can be viewed as a further indication of the difficulties associated with tax reform and trade liberalisation. 


\section{Appendix 1 Summary statistics}

\begin{tabular}{|c|c|c|c|c|c|c|}
\hline Variable & Income group & Obs. & Mean & $\begin{array}{l}\text { Std. } \\
\text { Dev. }\end{array}$ & Min & Max \\
\hline \multirow{4}{*}{$\begin{array}{l}\text { Gross fixed capital formation (\% of } \\
\text { GDP) }\end{array}$} & LI & 868 & 18.93 & 8.98 & -2.42 & 74.82 \\
\hline & MI & 894 & 22.72 & 7.11 & 5.2 & 63.85 \\
\hline & $\mathrm{HI}$ & 1124 & 23.09 & 5.32 & 4.35 & 46.95 \\
\hline & OECD & 859 & 22.52 & 3.96 & 9.85 & 39.73 \\
\hline \multirow{4}{*}{ Per capita GDP growth (\%) } & LI & 826 & 0.76 & 5.15 & -64.08 & 31.31 \\
\hline & MI & 857 & 1.98 & 4.55 & -35.46 & 18.23 \\
\hline & $\mathrm{HI}$ & 1079 & 1.94 & 3.28 & -21.54 & 15.01 \\
\hline & OECD & 823 & 1.97 & 2.8 & -12.47 & 9.74 \\
\hline \multirow{4}{*}{ Average years of schooling } & LI & 914 & 3.57 & 1.54 & 0.62 & 7.65 \\
\hline & MI & 953 & 6.88 & 2.05 & 0.23 & 11.04 \\
\hline & $\mathrm{HI}$ & 1137 & 9.07 & 1.86 & 3.51 & 13.05 \\
\hline & OECD & 866 & 9.44 & 1.83 & 3.55 & 13.05 \\
\hline \multirow{4}{*}{$\begin{array}{l}\text { Growth of working age population } \\
\text { (\%) }\end{array}$} & LI & 848 & 2.79 & 1.02 & -4.13 & 7.79 \\
\hline & MI & 878 & 2.2 & 1.28 & -2.06 & 13.38 \\
\hline & $\mathrm{HI}$ & 1083 & 1.22 & 1.16 & -1.23 & 10.82 \\
\hline & OECD & 827 & 0.95 & 0.84 & -1.23 & 4.83 \\
\hline \multirow{4}{*}{ Tax receipts (\% of GDP) } & LI & 655 & 12.79 & 7.55 & 1.12 & 56.61 \\
\hline & MI & 752 & 14.8 & 5.78 & 3.93 & 39.63 \\
\hline & $\mathrm{HI}$ & 1094 & 23.08 & 8.59 & 1.2 & 49.52 \\
\hline & OECD & 838 & 25.4 & 7.69 & 8.25 & 49.52 \\
\hline \multirow{4}{*}{ Direct taxes (\% of tax revenue) } & LI & 655 & 29.34 & 10.89 & 10.23 & 65.36 \\
\hline & MI & 752 & 30.92 & 13.58 & 0 & 77.25 \\
\hline & $\mathrm{HI}$ & 1094 & 51.79 & 15.18 & 0 & 82.73 \\
\hline & OECD & 838 & 54.67 & 13.65 & 16.17 & 82.73 \\
\hline \multirow{4}{*}{$\begin{array}{l}\text { Consumption taxes (\% of tax } \\
\text { revenue) }\end{array}$} & LI & 655 & 38.01 & 15.69 & 6.8 & 75.71 \\
\hline & MI & 752 & 43.79 & 18.06 & 1.36 & 99.74 \\
\hline & $\mathrm{HI}$ & 1094 & 40.8 & 13.21 & 3.26 & 73.72 \\
\hline & OECD & 838 & 42.78 & 12.48 & 16.26 & 73.71 \\
\hline \multirow{4}{*}{ Trade taxes (\% of tax revenue) } & LI & 655 & 32.65 & 17.06 & 2.74 & 80.04 \\
\hline & MI & 752 & 25.29 & 17.65 & 0 & 74.72 \\
\hline & $\mathrm{HI}$ & 1094 & 7.61 & 14.6 & 0 & 96.74 \\
\hline & OECD & 838 & 2.64 & 3.61 & 0 & 17.87 \\
\hline \multirow{4}{*}{ PIT (\% of tax revenue) } & LI & 434 & 13.57 & 9.01 & 0 & 48.65 \\
\hline & $\mathrm{Ml}$ & 573 & 10.15 & 8.62 & 0 & 43.67 \\
\hline & $\mathrm{HI}$ & 932 & 36.77 & 14 & 5.4 & 67.21 \\
\hline & OECD & 784 & 39.29 & 13.33 & 5.4 & 67.21 \\
\hline \multirow{4}{*}{ CIT (\% of tax revenue) } & LI & 434 & 13.37 & 8.02 & 1.87 & 69.75 \\
\hline & MI & 573 & 16.74 & 10.09 & 0.06 & 61.74 \\
\hline & $\mathrm{HI}$ & 932 & 13.64 & 7.3 & 0.92 & 48.54 \\
\hline & OECD & 784 & 12.82 & 6.76 & 0.92 & 44.67 \\
\hline
\end{tabular}




\section{Appendix 2 Country list (full sample)}

\section{Low-income:}

Bangladesh, Benin, Burundi, Cameroon, Central African Republic, Democratic Republic of Congo, Côte D'Ivoire, The Gambia, Ghana, Haiti, India, Kenya, Lesotho, Malawi, Mali, Mauritania, Mozambique, Nepal, Nicaragua, Niger, Pakistan, Papua New Guinea, Rwanda, Senegal, Sierra Leone, Sudan, Syrian Arab Republic, Tanzania, Togo, Uganda, Vietnam, Zambia, Zimbabwe.

\section{Middle-income:}

Albania, Algeria, Argentina, Barbados, Belize, Bolivia, Botswana, Bulgaria, Rep. of the Congo, Costa Rica, Cuba, Dominican Republic, Ecuador, Egypt, El Salvador, Fiji, Guatemala, Indonesia, Iran, Jordan, Maldives, Mauritius, Mongolia, Morocco, Namibia, Panama, Paraguay, Philippines, Romania, South Africa, Sri Lanka, Swaziland, Thailand, Tonga, Uruguay, Republic of Yemen.

\section{High-income:}

Australia, Austria, Bahrain, Barbados, Belgium, Canada, Chile, Cyprus, Denmark, Finland, France, Gabon, Germany, Greece, Hungary, Iceland, Ireland, Israel, Italy, Japan, Korea Rep., Kuwait, Luxembourg, Malaysia, Malta, Mexico, Netherlands, New Zealand, Norway, Poland, Portugal, Singapore, Spain, Sweden, Switzerland, Trinidad and Tobago, Turkey, United Kingdom, United States, Uruguay, Venezuela.

\section{OECD:}

Australia, Austria, Belgium, Canada, Chile, Denmark, Finland, France, Germany, Greece, Hungary, Iceland, Ireland, Israel, Italy, Japan, Korea Rep., Luxembourg, Mexico, Netherlands, New Zealand, Norway, Poland, Portugal, Sweden, Switzerland, Turkey, United Kingdom, United States. 


\section{References}

Acosta-Ormaechea, S. and Yoo, J. (2012) Tax Composition and Growth: A Broad CrossCountry Perspective, IMF Working Paper WP/12/257, International Monetary Fund

Afrobarometer (2014) Afrobarometer Online data analysis, available at <http://www.afrobarometer-online-analysis.com/aj/AJBrowserAB.jsp> accessed 10 May 2014

Arnold, J., Brys, B., Heady, C., Johansson, A., Schwellnus, C. and Vartia, L. (2011) 'Tax Policy for Economic Recovery and Growth', The Economic Journal 121(550): F59-F80

Barro, R. (1990) 'Government Spending in a Simple Model of Endogenous Growth', Journal of Political Economy 98:5: S103-S125

- and Lee, J. (2013) 'A new data set of educational attainment in the world, 1950-2010', Journal of Development Economics 104: 184-198

_ and Sala-i-Martin, X. (1995) Economic growth, New York: McGraw-Hill

Baunsgaard, T. and Keen, M. (2010) 'Tax revenue and (or?) trade liberalization', Journal of Public Economics 94(9): 563-577

Bleaney, M., Gemmell, N. and Kneller, R. (2001) 'Testing the endogenous growth model: public expenditure, taxation, and growth over the long run', Canadian Journal of Economics/Revue canadienne d'économique 34(1): 36-57

Bos, J., Economidou, C., Koetter, M. and Kolari, J. (2010) ‘Do all countries grow alike?', Journal of Development Economics 91(1): 113-127

Coakley, J., Fuertes, A. and Smith, R. (2006) 'Unobserved heterogeneity in panel time series models', Computational Statistics \& Data Analysis, 50(9): 2361-2380

De Hoyos, R. and Sarafidis, V. (2006) 'Testing for cross-sectional dependence in panel-data models, Stata Journal 6(4): 482-496

Easterly, W. and Rebelo, S. (1993) 'Fiscal policy and economic growth', Journal of Monetary Economics 32(3): 417-458

Eberhardt, M. (2012) 'Estimating panel time-series models with heterogeneous slopes', Stata Journal 12(1): 61-71

_ (2011) 'Panel time-series modeling: New tools for analyzing xt data', available at <http://repec.org/usug2011/UK11_Eberhardt.pdf> accessed 12 May 2014

_ Helmers, C. and Strauss, H. (2013) 'Do spillovers matter when estimating private returns to R\&D?', Review of Economics and Statistics 95(2): 436-448

— and Teal, F. (2011) 'Econometrics for grumblers: A new look at the literature on crosscountry growth empirics', Journal of Economic Surveys 25(1): 109-155

IMF (2011) Revenue Mobilization in Developing Countries, International Monetary Fund, available at <http://www.imf.org/external/np/pp/eng/2011/030811.pdf > accessed 5 December 2013 
King, R. and Rebelo, S. (1990) 'Public Policy and Economic Growth: Developing Neoclassical Implications', Journal of Political Economy 98(5): S126-S150

Kneller, R., Bleaney, M. and Gemmell, N. (1999) 'Fiscal policy and growth: evidence from OECD countries', Journal of Public Economics 74(2): 171-190

Lee, Y. and Gordon, R. (2005) 'Tax structure and economic growth', Journal of Public Economics 89(5): 1027-1043

Martinez-Mongay, C. (2000) ECFIN's effective tax rates: properties and comparisons with other tax indicators, European Commission, Directorate-General for Economic and Financial Affairs

Mendoza, E., Milesi-Ferretti, G. and Asea, P. (1997) 'On the ineffectiveness of tax policy in altering long-run growth: Harberger's superneutrality conjecture', Journal of Public Economics 66(1): 99-126

_ Razin, A. and Tesar, L. (1994) 'Effective tax rates in macroeconomics: Cross-country estimates of tax rates on factor incomes and consumption', Journal of Monetary Economics 34(3): 297-323

Myles, G. (2007) Economic growth and the role of taxation, report prepared for the OECD, University of Exeter and Institute for Fiscal Studies

OECD (2014) Fragile States 2014. Domestic Revenue Mobilisation in Fragile States, available at <http://www.oecd.org/dac/incaf/FSR-2014.pdf> accessed 11 June 2014

- (2013) What Drives Tax Morale?, Paris: OECD, <www.oecd.org/ctp/taxglobal/TaxMorale_march13.pdf> accessed 10 June 2014

Pesaran, M. (2006) 'Estimation and inference in large heterogeneous panels with a multifactor error structure', Econometrica 74(4): 967-1012

— and Smith, R. (1995). Estimating long-run relationships from dynamic heterogeneous panels. Journal of Econometrics 68(1): 79-113

Plosser, C. (1992) The search for growth, available at <kansascityfed.org> accessed 15 October 2013

Prichard, W., Cobham, A. and Goodall, A. (2014) The ICTD Government Revenue Dataset, ICTD Working Paper 19, Brighton: International Centre for Tax and Development

Riezman, R. and Slemrod, J. (1987) 'Tariffs and collection costs', Weltwirtschaftliches Archiv 123(3): 545-549

Schneider, F., Buehn, A., and Montenegro, C. (2010) 'New Estimates for the Shadow Economies all over the World', International Economic Journal 24(4): 443-461

Solow, R. (1956) 'A contribution to the theory of economic growth', Quarterly Journal of Economics 70(1): 65- 94

Swan, T. (1956) ‘Economic Growth and Capital Accumulation’, Economic Record 32(2): 334361 
Tanzi, V. and Zee, H. (2000) 'Tax policy for emerging markets: developing countries', National Tax Journal 53(2): 299-322

Thirlwall, A. (2006) Growth and Development $8^{\text {th }}$ Edition, Basingstoke and New York: Palgrave Macmillan

Todaro, M. and Smith, S. (2009) Economic Development, Essex: Pearson Education

UN Millennium Project (2005) Investing in Development: A Practical Plan to Achieve the Millennium Development Goals, New York

World Bank (2014) World Development Indicators, available at <http://data.worldbank.org/about/country-classifications/country-and-lending-groups> accessed 16 January 2014

World Values Survey (2014) World Values Survey Online Data Analysis, available at <http://www.worldvaluessurvey.org/WVSOnline.jsp> accessed 10 May 2014 


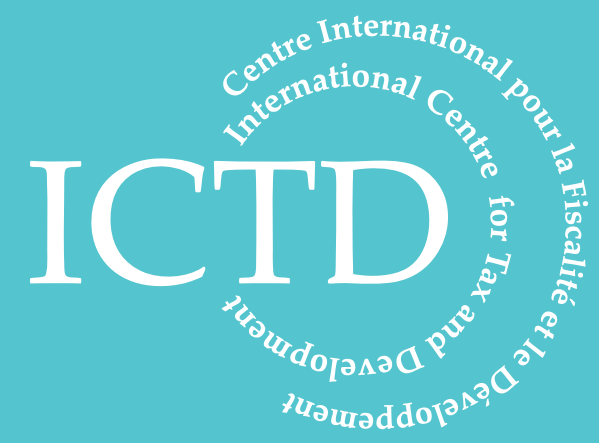

International Centre for Tax and Development at the Institute of Development Studies

Brighton BN1 9RE, UK

T: +44 (0) 1273606261

F: $+44(0) 1273621202$

E: info@ictd.ac

www.ictd.ac 